\title{
Prediction of Knowledge Management for Success of Franchise Hospitality in a Post-Pandemic Economy
}

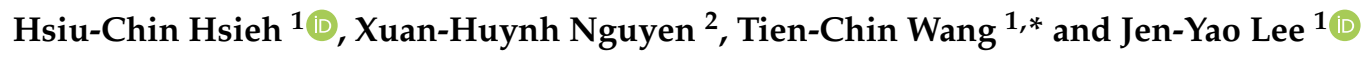 \\ 1 Department of International Business, National Kaohsiung University of Science and Technology, \\ Kaohsiung 80778, Taiwan; 1103405120@nkust.edu.tw (H.-C.H.); itjylee@nkust.edu.tw (J.-Y.L.) \\ 2 Hanoi School of Business and Management, Vietnam National University, Hanoi 100000, Vietnam; \\ huynhnx@hsb.edu.vn \\ * Correspondence: tcwang@nkust.edu.tw
}

Received: 21 September 2020; Accepted: 15 October 2020; Published: 21 October 2020

\begin{abstract}
Due to its unpredictability, the novel coronavirus (COVID-19) pandemic has changed the global business climate and commercial management practices in unprecedented ways. As a direct result of the pandemic, the hospitality and tourism sectors have shut down, and business failure rates have occurred exponentially. The franchise hospitality industry has experienced significant impact and challenged a basic understanding of knowledge management (KM) implementation in the face of the COVID-19 outbreak. A strategic KM implementation practice can not only guide a large-scale operation, but also adjust an organization's performance and competitiveness. The purpose of this study is to examine the influential criteria of success through effective KM implementation and to predict the probability of successful KM in a post-pandemic era. The conceptual framework for KM applies an analytic hierarchical prediction model reliant upon consistent fuzzy preference relations to assist the franchise hospitality sector's consciousness of the influential criteria. An empirical case study is used to apply pairwise comparisons used to determine the priority weights and two possible outcomes. The case study will assist franchise organizations to analyze whether or not to implement $\mathrm{KM}$, interdict application, or adopt revised actions. This assistance will enhance the success possibility of KM implementation within such a crisis environment. This study uses a case setting by assessing 15 franchises hospitality experts' opinions in Taiwan relevant to KM implementation.
\end{abstract}

Keywords: COVID-19; knowledge management; franchise; consistent fuzzy preference relations; hospitality industry; post-pandemic; influential criteria

\section{Introduction}

Franchise systems are a major commercial feature of the service distribution structure worldwide; as such, more than 143 industries are presently engaged in franchising, prevailed over by 50,000 companies, and surpassed by 800,000 retail involvements [1] Bretas and Alon [2] stated that Taiwan is among one of the top four countries worldwide with a number of franchise brands, using franchising as a tool to develop economy growth, job creation, and global dynamic market competition. Decisions regarding firm internationalization, as well as determining the important dimensions of the franchise hospitality format (i.e., trademark, compensation package, management approach, operating manuals and standards, quality control, marketing strategy and planning, and a managerial process of consultation with the franchise partners depend on knowledge management (KM) [2]. As the largest franchise industry, hospitality and tourism must choose among competing contracts, knowledge management transfer, opportunities to provide a high probability of success, and good brand value and reputation [3]. One of the greatest immediate existential challenges that the tourism and hospitality industry has faced is that the COVID-9 outbreak involves complicated 
commercial and social challenges among franchises, resulting in numerous adverse economic and social effects [4]. The unpredictability and implications of the pandemic crisis represent principal external criteria that can collapse the franchise hospitality industry entirely $[5,6]$. Although a number of unforeseen global crises have struck in the 21st century, none have had a more formidable impact on the franchise hospitality industry than the COVID-19 pandemic [7]. The pandemic has caused the franchise hospitality sector to undergo substantial financial shortfalls, combined with a near-complete shutdown of entire national economies [8]. The challenges of coping with COVID-19 involve many issues for industrial authorities when adapting their KM implementation to overcome the diverse problems impacting the franchise hospitality industry. Several challenges will undoubtedly remain after the pandemic ebbs; thus, the implementation of knowledge management (KM) has quickly become of practical and appropriate concern. Additionally, franchise organizations should establish effective and accurate KM that will encourage the development and transformational acceleration necessary in the post-pandemic stabilization phase [9].

The purpose of this study was to firstly determine the influential criteria of success through effective KM implementation and to predict the probability of successful KM in a post-pandemic era. This study reviews the current literature and academic journal articles, along with excerpts taken from industry journals, magazines, and other related materials focusing on COVID-19 issues in the franchise hospitality field. This activity is useful to broaden an understanding of academic, industrial, and governmental perceptions [10,11]. This study demonstrates an actual case study by interviewing 15 evaluators who are franchise hospitality experts located in Taiwan. Moreover, seven influential criteria were investigated by summarizing essential data divided into two sections; one key section addresses secondary data from an academic perspective, while a second section addresses primary data collected from 25 to 30 August 2020 by means of adopting experts' surveys and interviews.

Secondly, this study applied consistent fuzzy preference relations (CFPR) to illustrate an analytic hierarchical prediction model used to assist the franchise hospitality industry become more conscious of COVID-19's unprecedented impact [12]. Hence, pairwise comparisons were conducted to calculate and rank the priority weights of influential criteria and the two possible (success or failure) outcomes, before rating the best implementation for franchise sectors to adopt for accurate KM [13]. The proposed model can not only help franchise organizations to understand what criteria can be used to conduct successful decision-making processes, but also predict the probability of successful and appropriate strategies and actions that will pilot the franchise hospitality industry's implementation of KM in the post-pandemic future [14].

In conclusion, the cognitive model of KM is a conceptual framework described throughout this study, and it illustrates a set of relevant discussions and conclusions to predict the KM implementation useful for an organization to overcome the global crisis. This section highlights the theoretical and practical implications and future research directions for future research in this field. A significant research aspect of this study focuses on franchise hospitality during the COVID-19 outbreak as it relates to the widespread policy of social distancing $[15,16]$.

\section{The Review of the Professional and Academic Literature}

The COVID-19 outbreak has significantly created global economic, political, and social consequences worldwide. This unpredictable disaster of monumental importance has not only reduced business revenues, but also changed consumer behavior and demand [17-21]. The greatest consideration is merely to survive in an uncertain internal and external environment influencing possible global performance of productivity and competitiveness [22]. Therefore, the franchise hospitality sector must continuously examine both their explicit and their implicit management strategies to satisfy changeable consumer demand and sustainable development to enhance organizational performance [23]. In particular, KM can play a critical role during the COVID-19 outbreak; thus, accurate KM implementation can lead organizations toward survival during the pandemic while supporting successful performance. This study investigates a portion of the influential criteria 
necessary for successful KM implementation to take place. These criteria may be divided into seven recognizable dimensions: headquarters system, human resources (HR) strategy, corporate imagination, location advantage, innovation and transformation, marketing strategy, and crisis management [24].

\subsection{Headquarters System}

In franchise organizations, the greatest amount of complexity comes from transferring knowledge used to deal with challenges and access to organizational management. Kloutsiniotis and Mihail [25] claimed the franchise system should provide flexible managerial know-how to reach the franchisee's endeavors and benefits. The key headquarters' input is recognizing the inherent organizational nature which can accelerate successful change in the post-COVID-19 recovery phase. Furthermore, management must possess the knowledge and ability required to define the nature of the franchise hospitality diversity, support channel diversity, select franchise partner-members, and practice consistent management strategies. There are various divisions in an organization practicing a diverse KM framework using different knowledge bases and skill sets [26,27]. Especially when in the midst of a crisis, a team leader must act as an expert by planning, organizing, and monitoring the franchising members' performance and by evaluating the degrees of efficient performance. These points have become controversial issues in franchise organizations during the pandemic. Moreover, the headquarters system is based upon explicit knowledge management and transfer mechanisms since an improvement of consistency and standardization can best maintain the current business model, operational procedures, policy guidelines, quality controls, and brand standard documentation [28]. A superlative headquarters system can quickly recognize the importance of successful strategic management needed to share knowledge and to enhance a firm's ability to react faster to challenges and opportunities in the COVID-19 outbreak [29].

\subsection{Human Resources}

After the initial COVID-19 outbreak, a majority of the hospitality sector decided to follow both voluntary and government-mandated lockdowns or near shutdowns to the public. They had to address the urgent concerns of employees' assignments and working arrangements because the cost pressure of the current revenue challenges became a significant stressor on the franchise systems' ability to survive in a crisis. The immediate effects of the COVID-19 outbreak have caused widespread unemployment, resulted in unpaid leave, and created significant insurance interruptions and unavoidable labor problems [30,31]. Moreover, the hospitality sector's operational model has been forced to modify into a contactless service and delivery platform in continuance of the popular service and delivery model that protects food or product safety and hygiene while coping with pandemic prevention measures [32]. Throughout the ongoing pandemic outbreak, KM has been a process used by managers or monitors to encourage and to stimulate employees' improved absorptive capacities and acquisition of new knowledge or skills to meet the customer's continued expectations while still creating revenue [23,33]. Willis Towers Watson [34] affirmed that the KM system vis-á-vis HR performance can be used for decision-making in a rapidly shifting and uncertain environment. This will require organizations to resist the pressure to engage in short-term employment issues that seem essential in the chaos of the current environment, but which may compromise the long-term sustainability of the franchise hospitality organization.

\subsection{Corporate Imagination}

Understanding the culture and value of an organization can improve effective communication between stakeholders and the organization itself. Furthermore, different executive management methods are also directly impacted by the different cultures and values of an organization, so much so that the organization's problem-solving, time management, and decision-making methods will dramatically affect the corporation's bottom-line performance. Organizational values must be evaluated according to the internal and external environments of the organizations [35,36]. Evaluation criteria vary 
greatly and are represented as reputation, loyalty, truth, accountability, commitment, etc. Therefore, it is important to seek reliability through effective managerial procedures and efficiency to attract franchise partnership. Ultimately, the pandemic requires corporations to exhibit greater imagination and creativity in how to better deal with stakeholders and how to survive in a challenging time of crisis with their corporate reputation intact [37].

New franchisees must learn to adapt to the different cultures and values of the parent organization. Different cultural and value perceptions, coupled with concepts of overall organization, can cause franchisees to have feelings of insecurity, uncertainty, and dissatisfaction, especially in an uncertain and turbulent post-pandemic phase. As Nicola et al. [38] asserted, the motivation and satisfaction of franchisees increasingly affect customer satisfaction, translating into the profitability of the firms. The vibrant imagination of an organization is an essential criterion for reducing franchisee-partner turnover and improving the organization's reputation as the best franchise opportunity of choice [23].

\subsection{Location Advantage}

The advantage of choosing a good location used to be an essential criterion for the hospitality industry to enhance revenue, but it is also related to the expense associated with the location. An effective assessment of the business location depends on the nature of the owner's business according to the establishment of a new sector (i.e., population density, geographical location, possibility for future business development, consumption ability, etc.) [39,40]. In post-pandemic times, consumer behavior and outbreak prevention measures brought on by the need for social distancing and proper staffing levels will mean that people will stay at home and work more by means of remote and contactless service demands. This will result in a major transformation of the franchise hospitality service model. The conceptual location advantage has had to be rethought and reassessed to determine how a marketplace franchise hospitality performance (i.e., better sales and significant profits) can shape a unique brand reputation through an identified location advantage [41].

\subsection{Innovation and Transformation}

Globalism in the 21st century has received a significant challenge. Due to the COVID-19 outbreak, organizations have been forced to implement innovative and transformative sales methods to existing products or services in order to survive in the uncertain market environment [38]. Innovation describes the novel activities of an individual or of an organizational change to adapt to mutable external and internal environments. In sum, innovation subverts routines and dominant ways of thinking, it launches new process standards, it transforms tangible things and intangible behaviors, and it implements novel skills and knowledge. Innovation is directed by a creative orientation, and, within the global pandemic, four principal types of innovation have arisen: process, product, marketing, and organization. In addition, various combinations of contactless service and delivery methods have arisen to deal with consumers' dissatisfaction with current performance by leveraging novel technological and social opportunities [32,42,43]. For example, restaurants have cooperated with start-up digital and delivery platforms in a dynamic attempt to meet the burgeoning needs of the marketplace. In hotel or service sectors, implementing new digital technology has been used to conduct a contactless service model. Recently, most successful companies have devoted tremendous financial and manpower resources to these novel and innovative combinations. In fact, the central element of innovation is crucial to survive critical market battles and to fight the global crisis of the pandemic [44].

\subsection{Marketing Strategy}

Product characteristics in the hospitality industry (service sectors) develop differently according to the various marketing strategies pursued. These characteristics include intangibility, simultaneous production and consumption cycles, seasonality, perishability, uniqueness, parity, and complementarity. Each of the characteristic influences depends on how relevant services and products are developed, 
marketed, and sold within the pandemic's duration [45,46]. The fundamental marketing strategy of $\mathrm{KM}$ is a sophisticated management technique used for making a service organization profitable, thereby seeking the best business marketing strategies. In dynamically changing markets, organizations must adapt to market diversity in order to develop successful franchise relationships that will assist businesses to improve their strategic business performance and profitability. In the franchise hospitality context, strategic performance relates to an extensive market-based asset useful to achieve superior financial performance. With an ever-increasing market scope, the franchise hospitality sector can utilize its own intangible set of assets (e.g., unique firm competencies, brand image, physical assets, or human resources) across and within diverse markets. These assets will allow firms to reduce their investment risk and monitor costs by leveraging their own particular market knowledge [23,47,48].

\subsection{Crisis Management}

A review of current journals into research on the COVID-9 phenomenon identifies critical typologies and characteristics that will facilitate effective crisis management. Sigala [32] mentioned that executive researchers should not only design and implement a crisis recovery model and response strategy, but also build elastic knowledge and the capacity to address future crises [49]. Both knowledge and capacity are still lacking for the strategic measurement and prediction of hospitality impacts during the ongoing pandemic. Preliminary COVID-19 research has focused chiefly on how various organizations' published sources are used to determine the appropriate stages of prescriptive models and to assist organizations in their perception of proactive and strategic policies, with the best policy and action to be implemented in future [10,50].

Furthermore, Willis Towers Watson [34] developed the three phases of action for organizations and decision-makers to follow. The three phases provide the guiding principles as a management framework in navigating the COVID-19 crisis. The findings of the reviewed studies may prove useful to illustrate how decision-makers can implement strategies that will evaluate or implement action-steps at the various phases of the crisis and how to meet further distress.

The findings of the reviewed studies may prove useful to illustrate how decision-makers can implement strategies that will evaluate or implement action-steps at the various phases of the crisis and how to meet further distress.

Some studies investigated COVID-19's impact on the effectiveness of crisis response strategies, while some focused on the role an organization plays in affecting people's perceptions of a crisis [32]. Fong et al. [8] commented that crisis management should strengthen the relationship between an organization and an industry in order to discuss relevant improvement and accurate proceedings. To enhance comprehension, organizations must effectively roll out actions which pilot foremost understanding and to prevent further crisis by successfully managing the global pandemic. This study illustrated a comprehensive approach to synthesize the influential criteria, as shown in Table 1. 
Table 1. The seven influential criteria. KM, knowledge management.

\begin{tabular}{|c|c|c|}
\hline Criteria & Literature Review & Reference \\
\hline $\begin{array}{l}\text { Headquarters } \\
\text { System }\end{array}$ & $\begin{array}{l}\text { - The franchise system should provide flexible managerial know-how to reach the franchisee's endeavors and benefits. } \\
\text { - There are various divisions in an organization practicing a diverse KM framework using different knowledge bases and skill sets. } \\
\text { - The headquarters system is based upon explicit knowledge management and transfer mechanisms since an improvement in } \\
\text { consistency and standardization can best maintain the current business model, operational procedures, policy guidelines, quality } \\
\text { controls, and brand standard documentation. } \\
\text { - The headquarters system can quickly recognize the importance of successful strategic management needed to share knowledge } \\
\text { and to enhance a firm's ability to react faster to challenges and opportunities in the COVID-19 outbreak. }\end{array}$ & $\begin{array}{l}{[25]} \\
{[26,27]} \\
{[28]} \\
{[29]}\end{array}$ \\
\hline Human Resources & $\begin{array}{l}\text { - The effects of the COVID-19 outbreak have caused unavoidable labor problems. } \\
\text { - The hospitality sector's operational model has been forced to modify into a contactless service and delivery platform. } \\
\text { - } \quad \text { New knowledge or skills to meet the customer's continued expectations. } \\
\text { - The KM system vis-á-vis HR performance can be used for decision-making in a rapidly shifting and uncertain environment. }\end{array}$ & $\begin{array}{c}{[30,31]} \\
{[32]} \\
{[23,33]} \\
{[34]}\end{array}$ \\
\hline $\begin{array}{l}\text { Corporate } \\
\text { Imagination }\end{array}$ & $\begin{array}{l}\text { - Organizational values must be evaluated according to the internal and external environments of the organizations. } \\
\text { - The pandemic requires corporations to exhibit greater imagination and creativity. } \\
\text { - The vibrant imagination of an organization is an essential criterion for reducing franchisee-partner turnover and improving the } \\
\text { organization's reputation as the best franchise opportunity of choice. }\end{array}$ & $\begin{array}{l}{[35,36]} \\
{[37]} \\
{[23]}\end{array}$ \\
\hline $\begin{array}{l}\text { Location } \\
\text { Advantage }\end{array}$ & $\begin{array}{l}\text { - An effective assessment of the business location depends on the nature of the owner's business according to the establishment of } \\
\text { a new sector. } \\
\text { The conceptual location advantage has had to be rethought and reassessed to determine a marketplace franchise hospitality } \\
\text { performance as a unique brand reputation through identified location advantage. }\end{array}$ & $\begin{array}{c}{[39,40]} \\
{[41]}\end{array}$ \\
\hline $\begin{array}{l}\text { Innovation and } \\
\text { Transformation }\end{array}$ & $\begin{array}{l}\text { Due to the COVID-19 outbreak, organizations have been forced to implement innovative and transformative sales methods to } \\
\text { existing products or services in order to survive in the uncertain market environment. } \\
\text { Various combinations of contactless service and delivery methods have arisen to deal with consumers' dissatisfaction with } \\
\text { current performance by leveraging novel technological and social opportunities. } \\
\text { - The central element of innovation is crucial to survive critical market battles and to fight the global crisis of the pandemic. }\end{array}$ & $\begin{array}{l}{[38]} \\
{[32,42,43]} \\
{[44]}\end{array}$ \\
\hline $\begin{array}{l}\text { Marketing } \\
\text { Strategy }\end{array}$ & $\begin{array}{l}\text { - Each of the characteristic influences depends on how relevant services and products are developed, marketed, and sold within } \\
\text { the pandemic's duration. } \\
\text { These assets will allow firms to reduce their investment risk and monitor costs by leveraging their own particular } \\
\text { market knowledge. }\end{array}$ & $\begin{array}{c}{[45,46]} \\
{[23,47,48]}\end{array}$ \\
\hline
\end{tabular}


Table 1. Cont.

- $\begin{aligned} & \text { The executive researchers should not only design and implement a crisis recovery model and response strategy, but also build } \\ & \text { elastic knowledge and the capacity to address future crises. } \\ & \text { Various organizations' published sources are used to determine the appropriate stages of prescriptive models and to assist } \\ & \text { organizations in perception of proactive and strategic policies with the best policy and action to be implemented. } \\ & \text { Crisis } \\ & \text { Management }\end{aligned} \quad \begin{aligned} & \text { The three phases of action for organizations and decision-makers to follow provide the guiding principles as a management } \\ & \text { framework in managing the COVID-19 crisis with detailed key phases of action. } \\ & \text { [34] }\end{aligned}$
[32]
[8me studies investigated COVID-19's impact on the effectiveness of crisis response strategies, while some focused on the role an
The crisis management should strengthen the relationship between an organization and an industry in order to discuss relevant
improvement and accurate proceedings.




\section{Research Methodology}

The consistent fuzzy preference relations (CFPR) process may be used to evaluate the influential criteria needed to implement strategic knowledge management in the franchise hospitality industry. Herrera-Viedma et al. [51] proposed the CFPR research method for designing pairwise comparison preference prediction of decision models that enable decision-makers to represent the degree of preference from a set of alternatives. This is in addition to carry out an examination of the consistency of the decision-making process [51-53]. This study now presents a set of brief descriptive propositions and definitions which are applied throughout this study. The challenges of coping with COVID-19 involve many issues for industrial authorities when adopting the KM implementation to overcome the diverse impacts in the franchise hospitality industry. Several challenges will undoubtedly remain after the pandemic ebbs; thus, the implementation of knowledge management (KM) has quickly become of practical and appropriate concern.

The interview questions were as follows:

(1) What definition do you use to describe knowledge management of routine operation as franchise hospitality stakeholders?

(2) What processes do you use to implement KM strategies for market performance and competitiveness?

(3) What specific technology do you use to identify the influential criteria within the COVID-19 outbreak?

(4) What additional comments or insights would you suggest discussing?

(5) Moreover, seven major influential criteria were designed into a set of pairwise comparisons, to collect the experts' preference opinions.

\subsection{Fuzzy Preference Relations}

Definition 1. According to fuzzy preference relations $P$ on a set of alternatives, $X$ is represented by a positive preference relations matrix $P \subset X \times X$ with membership function $\alpha_{p}: X \times X \rightarrow[0,1]$. Furthermore, $p_{i j}=\alpha_{p}$ $\left(x_{i}, x_{j}\right)$ interprets the degree of the preference intensity of alternative $x_{i}$ over $x_{j}$. If $p_{i j}=\sum_{i=1}^{n} p_{i j}$ intimates indifference between $x_{i}$ and $x_{j}\left(x_{i}-x_{j}\right), p_{i j}=1$ denotes that $x_{i}$ is absolutely preferred to $x_{j}, p_{i j}=0$ represents that $x_{j}$ is absolutely preferred to $x_{i}$, and $p_{i j}>\frac{1}{2}$ represents that $x_{i}$ is preferred to $x_{i}\left(x_{i}>x_{j}\right)$.

In this study, the preference matrix $P$ is supposed to be an additive reciprocal [12],

$$
p_{i j}+p_{j i}=1 \forall i, j \in\{1,2, \ldots, n\}
$$

Proposition 1. Consider a set of alternatives, $X=\left\{x_{i}, \ldots, x_{n}\right\}$ related to the reciprocal multiplicative preference relations $A=\left(a_{i j}\right)$ with $a_{i j} \in\left[\frac{1}{9}, 9\right]$. In addition, the parallelism reciprocal additive fuzzy preference relationship between $P=\left(p_{i j}\right)$ and $p_{i j} \in[0,1]$ is stated as follows:

$$
p_{i j}=\mathrm{g}\left(a_{i j}\right)=\frac{1}{2}\left(1+\log _{9} a_{i j}\right)
$$

This study concentrates on the consistency of the decision model reliant upon fuzzy preference relations that are able to obtain the type of transformation function $g$ relatable to the research issues.

\subsection{Consistency of Fuzzy Preference Relations}

Proposition 2. Let $A=\left(a_{i j}\right)$ be a consistent multiplicative preference relationship, in which the parallelism reciprocal additive fuzzy preference relationship, $P=g(A)$, proves the additive transitivity property. 
Proof. $A=\left(a_{i j}\right)$ is deemed consistent, whereby $a_{i j} \cdot a_{j k}=a_{i k} \forall i, j, k$, or equivalently $a_{i j} \cdot a_{j k} \cdot a_{i k}=1 \forall i, j, k$. Logarithms on both sides are assumed,

$$
\log _{9} a_{i j}+\log _{9} a_{j k}+\log _{9} a_{k i}=0 \quad \forall i, j, k
$$

Equation (3) is then added before dividing by Equation (2), giving

$$
\frac{1}{2}\left(1+\log _{9} a_{i j}\right)+\frac{1}{2}\left(1+\log _{9} a_{j k}\right)+\frac{1}{2}\left(1+\log _{9} a_{k i}\right)=\frac{3}{2} \quad \forall i, j, k .
$$

The fuzzy preference relationship $P=g(A)$, where $p_{i j}=\frac{1}{2}\left(1+\log _{9} a_{i j}\right)$, affirms that

$$
p_{i j}+p_{j k}+p_{k i}=\frac{3}{2} \forall i, j, k \text {. }
$$

Undoubtedly, $P=g(A)$ verifies the additive transitivity property. In this study, the following definition of consistent fuzzy preference relations was considered:

Definition 2. A reciprocal additive fuzzy preference relationship $P=\left(p_{i j}\right)$ is consistent if

$$
p_{i j}+p_{j k}+p_{k i}=\frac{3}{2} \forall i, j, k=1, \ldots, n
$$

\subsection{Additive Transitivity Consistency of the Fuzzy Preference Relations}

Below, the term "additive consistency" is used to refer to the consistency of fuzzy preference relations with respect to the additive transitivity property.

Proposition 3. For a reciprocal fuzzy preference relationship $P=\left(p_{i j}\right)$, the following statements are equivalent:

$$
\begin{gathered}
p_{i j}+p_{j k}+p_{k i}=\frac{3}{2} \quad \forall i, j, k . \\
p_{i j}+p_{j k}+p_{k i}=\frac{3}{2} \quad \forall i<j<k .
\end{gathered}
$$

Proposition 4. A fuzzy preference relationship $P=\left(p_{i j}\right)$ is consistent if

$$
p_{i j}+p_{j k}+p_{k i}=\frac{3}{2} \quad \forall i \leq j \leq k
$$

Proposition 5. A reciprocal additive fuzzy preference relationship $P=\left(p_{i j}\right)$ constitutes the following:

$$
\begin{gathered}
p_{i j}+p_{j k}+p_{k i}=\frac{3}{2} \quad \forall i<j<k \\
p_{i(i+1)}+p_{(i+1)(i+2)}+\ldots+p_{(j-1) j}+p_{j i}=\frac{j-i+1}{2} \quad \forall i<j .
\end{gathered}
$$




\section{Framework to Evaluate the Influence of Criteria to Implement Knowledge Management (KM)}

\subsection{Evaluated Influential Criteria and Framework of the Evaluation Model}

This study illustrates an analytic hierarchical prediction model (see Figure 1) used to analyze the franchise hospitality industry of COVID-19's unprecedented impact [12]. The process comprises four dimensions: investigating the influential criteria, determining the weight of influential criteria, obtaining the ratings of outcome, and evaluating KM implementation. The key significance of this research contribution can not only help franchise organizations to understand what criteria can be used to conduct successful decision-making processes, but also predict the probability of successful and accurate strategies and actions that will pilot the franchise hospitality industry to overcome the challenges in the post-pandemic future [14].

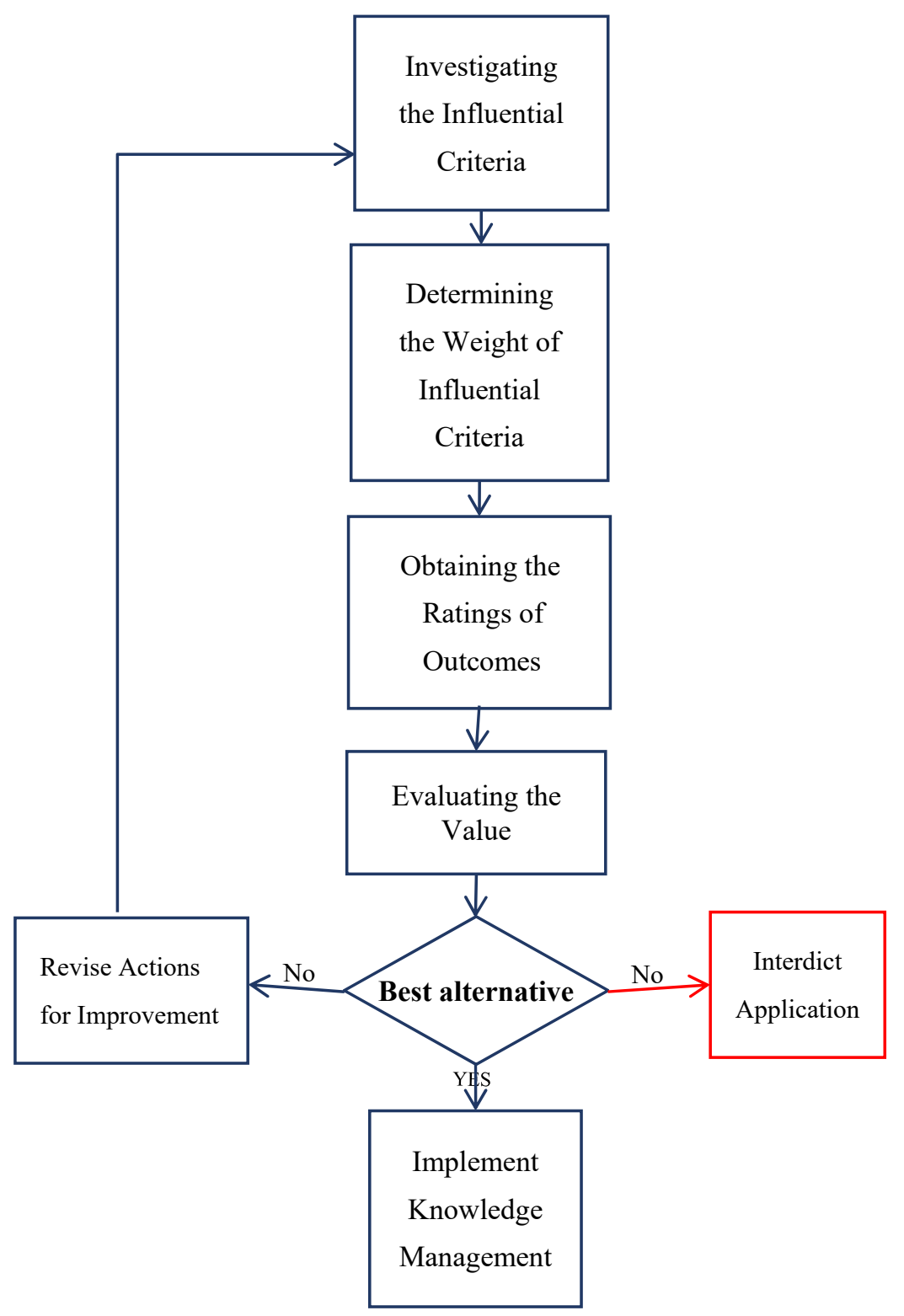

Figure 1. The framework for evaluating knowledge management implementation.

A total of 15 questionnaires were dispatched, and evaluators included four franchisees, four franchisors, four scholars, and three franchise hospitality employees. All of the evaluators were involved in the franchise hospitality field for $10-40$ years, with an immediate understanding 
of the COVID-19 outbreak situation as it unfolded [25]. A clear KM model can guide the hospitality sector to overcome the global crisis. Evaluators identified KM's influence to identify and implement successful criteria and attributes. These criteria could be summarized as follows: $C_{1}$ headquarters system; $C_{2}$ human resources; $C_{3}$ corporate imagination; $C_{4}$ location advantage; $C_{5}$ innovation and transformation $C_{6}$ marketing strategy; $C_{7}$ crisis management. An analytic hierarchy framework reliant upon seven major influential criteria is illustrated in Figure 2 [12,53].

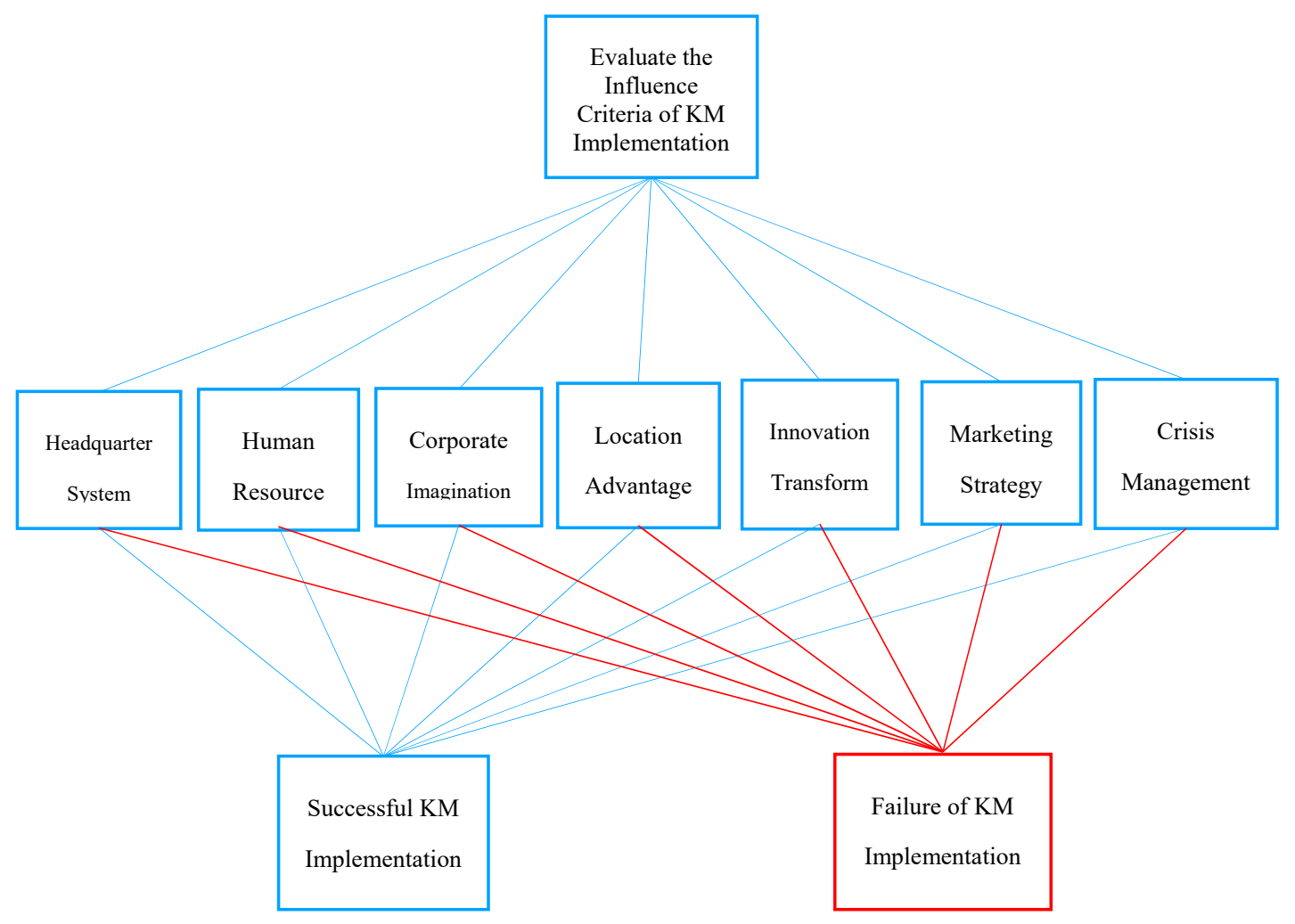

Figure 2. The analytic hierarchy framework of this study.

$C_{1}-$ Headquarters system. The organizational structure of the general headquarters system includes the complete operational policy of the franchise system, the stability of the franchisee's financial position, the vertical integration of channels, the standardization of processes, the degree of continuous innovation, and the guidance ability of the franchise enterprise [54]. High intensity and incentive KM represent a high probability of success and eventual implementation $[55,56]$.

$\mathrm{C}_{2}$ - Human resources. This includes appropriate staff experience, specialization, and capacity to create knowledge, develop innovative and effective training programs, and provide equal opportunities for appraisal and improvement [57]. Human resources performance can be identified as an influential criterion, including role perception, attitude, motivation, and improvement of performance variables. For staff, successful performance brings rewards that lead to job satisfaction and financial success for organization [58-60].

$\mathrm{C}_{3}$ - Corporate Imagination. A corporation's overall image includes the enterprise's reputation, logo, shop decoration, and design branding ability. A good corporate imagination has a positive impact on perceived organizational culture and valuation because of more precise and efficient communication with customers [61,62]. Corporate imagination may be considered as an intangible asset used to develop commitment and trust that will enhance marketing productivity and competition [63].

$\mathrm{C}_{4}$-Location advantage. Choosing a good location used to be an essential criterion for the franchise hospitality industry to enhance revenue, but it is also relatively expensive. It is necessary to assess the location of the hospitality business according to the nature of the owner's business, and to determine 
where the best location exists according to population density, the geographical location, the future development of the business, consumption ability, etc. [64].

$C_{5}$-Innovation and transformation. This criterion involves four processes: product, service, marketing and organizational technology, and nontechnology innovation. Due to the COVID-19 outbreak, the process of innovation has transformed into the implementation of a new service structure and delivery method or novelty associated with improved digital customer service. Innovation is considered to have a clear positive effect on financial performance, transformation, and improvement $[65,66]$.

$\mathrm{C}_{6}-$ Marketing strategy. Marketing capabilities can be assessed as a combination of a marketing plan, the customer relationship, psychological consumption and marketing mix strategies, advertising, promotional activities, matching of goods, interaction with customers, an understanding of consumerism, and an understanding of channels [67]. In a time such as this, an appropriate marketing consortium strategy may enhance the marketing productivities and competition of a firm $[28,68]$.

$C_{7}$-Crisis management. With respect to the knowledge and capacity to affect crisis management, the level of complexity of the COVID-19 pandemic may be regarded as a natural disaster, an economic crisis, social-political crisis, and hospitality demand crisis rolled into one. Organizations are still researching knowledge that will help to understand the overall effect of and how to deal with this global crisis [50,69].

\subsection{The Analytic Hierarchy Process for Evaluating the Influence of Criteria}

\subsubsection{Linguistic Variables}

This study compared criterion pairs with evaluator-indicated values for a set of criteria, such as the score representing the preference level of the first criterion when compared with a second criterion by utilizing linguistic variables such as "equally important (EQ)", "moderately important (MO)", "strongly important (ST)", "very strong importance (VS)", and "absolutely important (AB)", as well as by applying a nine-level scale with values indicated by actual numbers (see Table 2).

Table 2. Linguistic variables for priority weights of influential criteria.

\begin{tabular}{cc}
\hline Definition & Intensity of Importance \\
\hline Equally important (EQ) & 1 \\
Weakly more important (WK) & 3 \\
Strongly more important (ST) & 5 \\
Very strongly more important (VS) & 7 \\
Absolutely more important (AB) & 9 \\
Intermediate values used to represent compromise & $2,4,6,8$ \\
\hline
\end{tabular}

In addition, linguistic variables such as "very high $(\mathrm{VH})$ ", "high $(\mathrm{H})$ ", and "fair $(\mathrm{F})$ " were simultaneously used to evaluate the prediction of success or failure indicative of each influential criterion (see Table 3).

Table 3. Linguistic variables for the priority rating of possible outcome.

\begin{tabular}{cc}
\hline Definition & Intensity of Importance \\
\hline Fair $(\mathrm{F})$ & 1 \\
High $(\mathrm{H})$ & 3 \\
Very high $(\mathrm{VH})$ & 5 \\
Intermediate values used to represent compromise & 2,4 \\
\hline
\end{tabular}




\subsubsection{Consistent Fuzzy Preference Relations for Weighting the Influential Criteria}

This study considered the analytic efficiency by using the reciprocal additive CFPR's established computational simplicity of only requiring $n-1$ comparisons for a set of $n$ criteria. The processes for establishing the reciprocal additive CFPR for prioritizing the influential criteria are given below [52]:

(1) This study established pairwise comparison matrices for $n$ criteria $\left(C_{i}, i=1,2, \ldots, n\right)$ in the dimension of a hierarchical system. Evaluators $\left(C_{k}, k=1,2, \ldots, m\right)$ provided the essential pairwise criteria for a set of $n-1$ preference values $\left(a_{12}, a_{23}, \ldots, a_{(n-1) n}\right)$, as shown below.

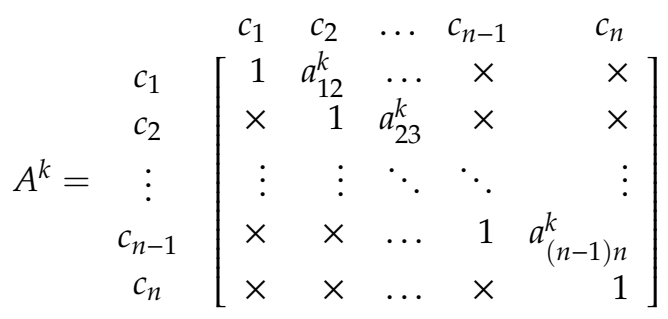

where $a_{i j}^{k}$ indicates the preference intensity toward influential criteria $i$ and $j$ as compared by evaluator $k, a_{i j}=1$ represents indifference between influential criteria $i$ and $j, a_{i j}=3,5,7,9$ evidence that criterion $i$ is comparatively more important than criterion $j$, and $a_{i j}=\frac{1}{3}, \frac{1}{5}, \frac{1}{7}, \frac{1}{9}$ denotes that influential criterion $i$ is less important than criterion $j$. The symbol " $\times$ " represents the preservation of $a_{i j}^{k}$, which denotes an opposite comparison [43].

(2) The preference value $a_{i j}^{k}$ was transformed into $p_{i j}^{k}$ utilizing an interval scale $[0,1]$ before deriving the preserved $p_{i j}^{k}$ on the basis of the reciprocal transitivity property, as shown below.

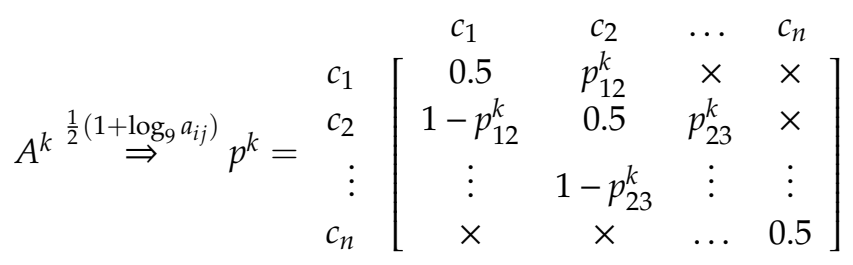

where $p_{i j}=0.5$ represents indifference between criteria $i$ and $j, p_{i j}=1$ indicates that criterion $i$ is absolutely more important than criterion $j$, and $p_{i j}=0$ represents that criterion $i$ is absolutely less important than criterion $j$. The remaining variable $p_{i j}^{k}$ can be applied using Equations (1) and (11) in an interval $[a, 1+a](a>0)$ to exchange the acquired values with a transformed function that preserves the reciprocity and additive consistency. The transformation function $(x)$ is stated below [51].

$$
\begin{gathered}
f:[-\mathrm{a}, 1+\mathrm{a}] \underset{\mathrm{a}}{\rightarrow}[0,1] \\
f(x)=\frac{\chi+\mathrm{a}}{1+2 \mathrm{a}}
\end{gathered}
$$

The transformation function is formulated below [70].

$$
f\left(p_{i j}^{k}\right)=\frac{p_{i j}^{k}+\mathrm{a}}{1+2 \mathrm{a}}
$$

It represents the absolute value of the maximum positive value or minimum negative value minus one in the preference decision matrix [52,71].

(3) The evaluators' opinions were pulled to acquire the aggregated priority weights of influential criteria. In addition, $p_{i j}^{k}$ was used to indicate transformed the fuzzy preference value of evaluator 
$k$ for evaluating the criteria $i$ and $j$. The notation of the average integrated values of $m$ evaluators is described below [72].

$$
p_{i j}=\frac{1}{m}\left(p_{i j}^{1}+p_{i j}^{2}+\ldots+p_{i j}^{m}\right)
$$

(4) Normalized fuzzy preference relation matrix $q_{i j}$ was aggregated to refer to the normalized fuzzy preference values of each criterion as follows:

$$
q_{i j}=\frac{1}{n} \sum_{i=1}^{n} p_{i j}
$$

(5) The variable $\bar{\omega}_{i}$ represents the average priority weight of influential criteria, whereas $n$ denotes the number of influential criteria; thus, the priority of each criterion can be defined as

$$
\bar{\omega}_{i}=\frac{q_{i j}}{\sum_{i=1}^{n} q_{i j}}
$$

\subsubsection{Defining the Priority Ratings for Possibility of Outcome Complying with Each Criterion}

The evaluators assessed subjective evaluations inspecting the preference ratings of possible outcomes $A u(u=1,2, \ldots, t)$ complying with each influential criterion as a linguistic variable, as shown in Table 3.

(1) For each influential criterion, the evaluators selected the two possible outcomes for a set of $t-1$ preference data $\left\{b_{12}, b_{23}, \ldots, b_{(t-1) t}\right\}$ as shown below.

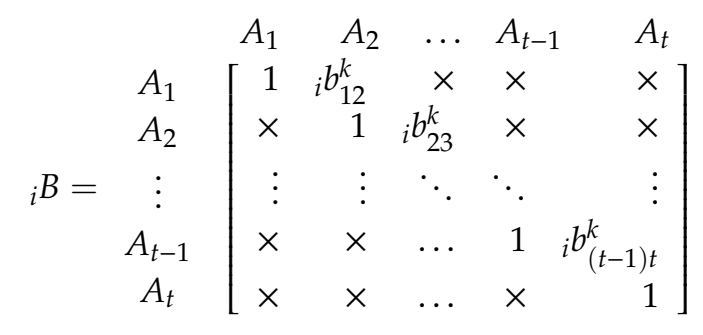

where ${ }_{i} b_{u v}^{k}$ indicates the evaluation value assigned by evaluator $k$ to calculate possible outcomes $A u$ and $A v$ according to influential criterion $i$.

(2) Moreover, the preference value ${ }_{i} b_{u v}^{k}$ was transformed in the range $\left[\frac{1}{5}, 5\right]$ into ${ }_{i} q_{u v}^{k}$ using an interval scale $[0,1]$, whereby the preservation of $i q_{u v}^{k}$ can be acquired utilizing the reciprocal transitivity property as follows:

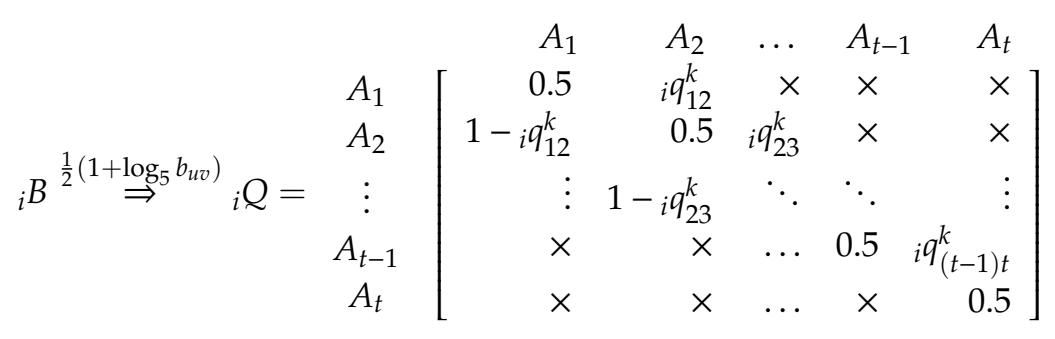

(3) The suggestions of evaluators were pulled to rate the synthetically transformed possible outcome. Utilizing ${ }_{i} q_{u v}^{k}$ represents the transformed fuzzy preference value of evaluator $k$ for evaluating 
possible outcomes $A u$ and $A v$ in terms of influential criterion $i$. The average value integrated the assessment values of $m$ evaluators as follows:

$$
{ }_{i} q_{u v}^{k}=\frac{1}{m}\left({ }_{i} q_{u v}^{1}+{ }_{i} q_{u v}^{2}+\ldots+{ }_{i} q_{u v}^{m}\right),
$$

where $m$ evaluators participated in the evaluation process.

(4) For the synthetically normalized fuzzy preference rating of possible outcomes, $i \lambda_{u v}$ was used to represent the normalized rating of possible outcomes $A u$ and $A v$ in terms of influential criterion $i$.

$$
{ }_{i} \lambda_{u v}=\frac{{ }_{i} q_{u v}}{\sum_{u=1}^{t}{ }_{i} q_{u v}} u, v=1,2, \ldots t .
$$

(5) As a consequence, $i \bar{\phi}_{u}$ representing the average rating of possible outcome $A u$ with respect to influential criterion $i$ was supplied. The appetence rating of each possible outcome could be acquired as follows

$$
{ }_{i} \bar{\phi}_{u}=\frac{1}{t} \sum_{v=1}^{t} \lambda_{u v}
$$

where $t$ presents the number of possible outcomes.

\subsection{Acquiring the Priority Weight for Prediction}

The priority weights were multiplied by the possible outcomes; then, a predicted value $\mathrm{Z} u$ for probability of success or failure was acquired.

$$
Z_{u}=\sum_{i=1}^{n}{ }_{i} \bar{\phi}_{u} \bar{\omega}_{i}
$$

where $\bar{\omega}_{i}$ indicates the aggregated weight of influential criterion $i$, and ${ }_{i} \bar{\phi}_{u}$ indicates the rating of possible outcome $A u$ with respect to influential criterion $i$. The prediction weight 0.5 denotes an approximately 50/50 probability of success or failure in KM implementation.

\section{Empirical Case for Predicting Possibility of Success of KM Implementation}

This study demonstrates KM in the franchise hospitality industry during the COVID-19 pandemic as an example to create the research framework. Expert questionnaires with linguistic variables, as shown in Table 2, were dispatched, and a conducted survey of 15 evaluators was used to investigate the real situation during the COVID-19 outbreak. Seven major influential criteria were summarized via interviews with the evaluators mentioned previously. Pairwise comparisons resulting from computational analysis to acquire the priority weights were used to assess the problem of determining how the franchising sector applies accurate KM to support the hospitality industry during this time of global crisis.

\subsection{Weight Calculation of the Influential Criteria}

(1) According to the 15 evaluators' interviews, seven influential criteria were indicated, as shown in Table 4, using $n$ pairwise comparison matrices from a number of $n-1$ contiguous criteria $\left\{a_{12}, a_{23}, \ldots, a_{78}\right\}$ assembled into linguistic terms [73]. 
Table 4. The linguistic terms describing the seven criteria evaluated by 15 evaluators.

\begin{tabular}{|c|c|c|c|c|c|c|c|c|c|c|c|c|c|c|c|c|}
\hline & $\mathrm{E}_{1}$ & $E_{2}$ & $E_{3}$ & $\mathrm{E}_{4}$ & $E_{5}$ & $\mathbf{E}_{6}$ & $\mathrm{E}_{7}$ & $\mathrm{E}_{8}$ & $\mathrm{E}_{9}$ & $\mathbf{E}_{10}$ & $\mathbf{E}_{11}$ & $\mathbf{E}_{12}$ & $\mathbf{E}_{13}$ & $\mathbf{E}_{14}$ & $\mathbf{E}_{15}$ & \\
\hline$C_{1}$ & WK & EQ & LSLV & WK & VT & $\mathrm{AB}$ & AV & $\mathrm{AB}$ & VS & $\mathrm{AB}$ & $\mathrm{AV}$ & LAB & LVS & $\mathrm{AB}$ & WK & $\overline{C_{2}}$ \\
\hline$C_{2}$ & ST & LVLA & LST & WK & LVS & LVS & VS & VS & LAB & EQ & LSLV & LAB & LVLA & $\mathrm{AB}$ & EQ & 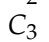 \\
\hline$C_{3}$ & VT & WE & EQ & LWLS & VS & LAB & LWK & LAB & LVS & ST & LAB & $\mathrm{AB}$ & AV & $\mathrm{AB}$ & $\mathrm{AB}$ & \\
\hline$C_{4}$ & WK & ST & VT & WK & LVS & VS & VS & VS & VS & SW & LST & LST & VS & $\mathrm{AV}$ & $\mathrm{AB}$ & \\
\hline$C_{5}$ & LSLV & LSLV & LVS & EQ & LVS & LVS & LSLV & EQ & $\mathrm{AV}$ & LST & LVLA & LVS & VS & $\mathrm{AV}$ & VS & c \\
\hline$C_{6}$ & EQ & LSLV & LSLV & LWK & EQ & LVLA & LVS & LVLA & LAB & WK & LVLA & LVS & LVLA & $\mathrm{AV}$ & $\mathrm{AB}$ & . \\
\hline
\end{tabular}

(2) The first evaluator's ( $\left.E_{1}\right)$ assessment was taken as an example (see Table 5). The fuzzy preference values presented in Table 2 and the linguistic terms could be transferred into parallelism scores as shown in Table 6.

Table 5. Fuzzy preference pairwise comparisons matrix of evaluator 1.

\begin{tabular}{cccccccc}
\hline $\mathrm{E}_{1}$ & $C_{1}$ & $C_{2}$ & $C_{3}$ & $C_{4}$ & $C_{5}$ & $C_{6}$ & $C_{7}$ \\
\hline$C_{1}$ & 1.0000 & $\mathrm{WK}$ & - & - & - & - & - \\
$C_{2}$ & - & 1.0000 & $\mathrm{ST}$ & - & - & - & - \\
$C_{3}$ & - & - & 1.0000 & $\mathrm{VT}$ & - & - & - \\
$C_{4}$ & - & - & - & 1.0000 & $\mathrm{WK}$ & - & - \\
$C_{5}$ & - & - & - & - & 1.0000 & $\mathrm{LSLV}$ & - \\
$C_{6}$ & - & - & - & - & - & 1.0000 & EQ \\
$C_{7}$ & - & - & - & - & - & - & 1.0000 \\
\hline
\end{tabular}

(3) Then, the linguistic terms were transferred into parallelism scores (see Table 6).

Table 6. The linguistic terms into parallel scores.

\begin{tabular}{cccccccc}
\hline $\mathrm{E}_{1}$ & $C_{1}$ & $C_{2}$ & $C_{3}$ & $C_{4}$ & $C_{5}$ & $C_{6}$ & $C_{7}$ \\
\hline$C_{1}$ & 1.0000 & 3 & - & - & - & - & - \\
$C_{2}$ & - & 1.0000 & 5 & - & - & - & - \\
$C_{3}$ & - & - & 1.0000 & 6 & - & - & - \\
$C_{4}$ & - & - & - & 1.0000 & 3 & - & - \\
$C_{5}$ & - & - & - & - & 1.0000 & $1 / 6$ & - \\
$C_{6}$ & - & - & - & - & - & 1.0000 & 1 \\
$C_{7}$ & - & - & - & - & - & - & 1.0000 \\
\hline
\end{tabular}

As seen in Table 2, evaluators indicated values for a number of criteria, such as the score $\left(a_{12}\right)$ representing the preference level of the first criterion $\left(C_{1}\right)$ when compared with a second criterion $\left(C_{2}\right)$. For example, suppose $a_{12}$ is the ratio scale of $1-9$ for a criterion, where $a_{12}=1$ indicates equivalence between $C_{1}$ and $C_{2}$, and $a_{12}=9$ indicates that $C_{1}$ is absolutely preferred to $C_{2}$. On the other hand, $a_{12}=3$ denotes that $C_{1}$ is moderately preferred to $C_{2}$. Lastly, in terms of linguistic variables, $a_{56}=1 / 6$ denotes that $C_{1}$ is less important than $C_{2}$.

(4) The elements were transformed by applying Equation (2) (listed in Table 7) into an interval [0, 1], as shown below.

$$
\begin{aligned}
& p_{12}=\left(1+\log _{9} 3.0000\right) / 2=0.7500, p_{45}=\left(1+\log _{9} 3.0000\right) / 2=0.7500 \\
& p_{23}=\left(1+\log _{9} 5.0000\right) / 2=0.8662, p_{56}=\left(1+\log _{9} 0.1667\right) / 2=0.0923 \\
& p_{34}=\left(1+\log _{9} 6.0000\right) / 2=0.9077, p_{67}=\left(1+\log _{9} 1.0000\right) / 2=0.5000
\end{aligned}
$$


Table 7. Linguistic terms transformed into values.

\begin{tabular}{cccccccc}
\hline $\mathrm{E}_{1}$ & $C_{1}$ & $C_{2}$ & $C_{3}$ & $C_{4}$ & $C_{5}$ & $C_{6}$ & $C_{7}$ \\
\hline$C_{1}$ & 1.0000 & 3.0000 & - & - & - & - & - \\
$C_{2}$ & - & 1.0000 & 5.0000 & - & - & - & - \\
$C_{3}$ & - & - & 1.0000 & 6.0000 & - & - & - \\
$C_{4}$ & - & - & - & 1.0000 & 3.0000 & - & - \\
$C_{5}$ & - & - & - & - & 1.0000 & 0.1667 & - \\
$C_{6}$ & - & - & - & - & - & 1.0000 & 1.0000 \\
$C_{7}$ & - & - & - & - & - & - & 1.0000 \\
\hline
\end{tabular}

The evaluation score could be calculated by applying Equations (1) and (11) with $p_{21}, p_{31}, p_{71}, p_{72}$, and $p_{27}$.

$$
\begin{gathered}
p_{21}=1-p_{12}=1-0.7500=0.2500, \\
p_{31}=\frac{3-1+1}{2}-p_{12}-p_{23}=1.5-0.7500-0.8662=-0.1162, \\
p_{71}=\frac{7-1+1}{2}-p_{12}-p_{23}-p_{34}-p_{45}-p_{56}-p_{67}, \\
=3.5-0.7500-0.8662-0.9077-0.7500-0.0923-0.5000=-0.3662, \\
p_{72}=\frac{7-2+1}{2}-p_{23}-p_{34}-p_{45}-p_{56}-p_{67}, \\
=3-0.8662-0.9077-0.7500-0.0923-0.5000=-0.1162, \\
p_{27}=1-p_{72}=1-(-0.1162)=1.1162
\end{gathered}
$$

The fuzzy preference relation matrix for the seven influential criteria evaluated by $E_{1}$ is shown in Table 8.

Table 8. Consistent fuzzy preference relation matrix of criteria evaluated by $\mathrm{E}_{1}$.

\begin{tabular}{cccccccc}
\hline $\mathrm{E}_{1}$ & $C_{1}$ & $C_{2}$ & $C_{3}$ & $C_{4}$ & $C_{5}$ & $C_{6}$ & $C_{7}$ \\
\hline$C_{1}$ & 0.5000 & 0.7500 & 1.1162 & 1.5240 & 1.7740 & 1.3662 & 1.3662 \\
$C_{2}$ & 0.2500 & 0.5000 & 0.8662 & 1.2740 & 1.5240 & 1.1162 & 1.1162 \\
$C_{3}$ & -0.1162 & 0.1338 & 0.5000 & 0.9077 & 1.1577 & 0.7500 & 0.7500 \\
$C_{4}$ & -0.5240 & -0.2740 & 0.0923 & 0.5000 & 0.7500 & 0.3423 & 0.3423 \\
$C_{5}$ & -0.7740 & -0.5240 & -0.1577 & 0.2500 & 0.5000 & 0.0923 & 0.0923 \\
$C_{6}$ & -0.3662 & -0.1162 & 0.2500 & 0.6577 & 0.9077 & 0.5000 & 0.5000 \\
$C_{7}$ & -0.3662 & -0.1162 & 0.2500 & 0.6577 & 0.9077 & 0.5000 & 0.5000 \\
\hline
\end{tabular}

Table 8 lists the $p_{13}, p_{31}, p_{14}, p_{41}, p_{15}, p_{51}, p_{16}, p_{61}, p_{17}, p_{71}, p_{24}, p_{42}, p_{25}, p_{52}, p_{26}, p_{62}, p_{27}, p_{72}, p_{35}$, $p_{53}$ elements not found in the interval $[0,1]$. Therefore, Equation (15) presents the linear transformation applied to confirm the reciprocity and additive transitivity for the preference relations matrix (see Table 9). 
Table 9. Linear solution for transformation matrix of criteria.

\begin{tabular}{cccccccc}
\hline $\mathrm{E}_{1}$ & $C_{1}$ & $C_{2}$ & $C_{3}$ & $C_{4}$ & $C_{5}$ & $C_{6}$ & $C_{7}$ \\
\hline$C_{1}$ & 0.5000 & 0.5981 & 0.7419 & 0.9019 & 1.0000 & 0.8400 & 0.8400 \\
$C_{2}$ & 0.4019 & 0.5000 & 0.6437 & 0.8038 & 0.9019 & 0.7419 & 0.7419 \\
$C_{3}$ & 0.2581 & 0.3563 & 0.5000 & 0.6600 & 0.7581 & 0.5981 & 0.5981 \\
$C_{4}$ & 0.0981 & 0.1962 & 0.3400 & 0.5000 & 0.5981 & 0.4381 & 0.4381 \\
$C_{5}$ & 0.0000 & 0.0981 & 0.2419 & 0.4019 & 0.5000 & 0.3400 & 0.3400 \\
$C_{6}$ & 0.1600 & 0.2581 & 0.4019 & 0.5619 & 0.6600 & 0.5000 & 0.5000 \\
$C_{7}$ & 0.1600 & 0.2581 & 0.4019 & 0.5619 & 0.6600 & 0.5000 & 0.5000 \\
\hline
\end{tabular}

(5) The calculated procedures illustrated the fuzzy preference relations matrices of another 14 evaluators; moreover, the aggregated pairwise comparison matrix of the 15 evaluators was acquired by applying Equation (16), as shown in Table 10.

Table 10. Aggregated pairwise comparison matrices of the 15 evaluators.

\begin{tabular}{cccccccc}
\hline $\mathrm{E}$ & $C_{1}$ & $C_{2}$ & $C_{3}$ & $C_{4}$ & $C_{5}$ & $C_{6}$ & $C_{7}$ \\
\hline$C_{1}$ & 0.5000 & 0.6050 & 0.5729 & 0.5655 & 0.6723 & 0.6066 & 0.5040 \\
$C_{2}$ & 0.3950 & 0.5000 & 0.4678 & 0.4604 & 0.5673 & 0.5015 & 0.3990 \\
$C_{3}$ & 0.4271 & 0.5322 & 0.5000 & 0.4926 & 0.5995 & 0.5337 & 0.4311 \\
$C_{4}$ & 0.4345 & 0.5396 & 0.5074 & 0.5000 & 0.6069 & 0.5411 & 0.4386 \\
$C_{5}$ & 0.3277 & 0.4327 & 0.4005 & 0.3931 & 0.5000 & 0.4342 & 0.3317 \\
$C_{6}$ & 0.3934 & 0.4985 & 0.4663 & 0.4589 & 0.5658 & 0.5000 & 0.3974 \\
$C_{7}$ & 0.4960 & 0.6010 & 0.5689 & 0.5614 & 0.6683 & 0.6026 & 0.5000 \\
Total & 2.9737 & 3.7089 & 3.4838 & 3.4319 & 4.1801 & 3.7197 & 3.0019 \\
\hline
\end{tabular}

(6) Equation (17) was applied to normalize the aggregated pairwise comparison matrix, where an example is shown below using $q_{12}$.

$$
q_{12}=0.6050 /(0.6050+0.5000+0.5322+0.5396+0.4327+0.4985+0.6010)=0.1631
$$

The priority weight of every influential criterion was acquired by applying Equation (18). The priority weight and rank of every influential criterion according to the 15 evaluators is indicated in Table 11.

Table 11. Normalized matrix of priority weight and rank of influential criteria.

\begin{tabular}{ccccccccccc}
\hline $\mathrm{E}$ & $\boldsymbol{C}_{1}$ & $\boldsymbol{C}_{2}$ & $\boldsymbol{C}_{3}$ & $\boldsymbol{C}_{4}$ & $\boldsymbol{C}_{5}$ & $\boldsymbol{C}_{6}$ & $\boldsymbol{C}_{7}$ & Total & Weight & Ranking \\
\hline$C_{1}$ & 0.1681 & 0.1631 & 0.1644 & 0.1648 & 0.1608 & 0.1631 & 0.1679 & 1.1523 & 0.1658 & 1 \\
$C_{2}$ & 0.1328 & 0.1348 & 0.1261 & 0.1342 & 0.1357 & 0.1348 & 0.1329 & 0.9314 & 0.1340 & 5 \\
$C_{3}$ & 0.1436 & 0.1435 & 0.1348 & 0.1435 & 0.1434 & 0.1435 & 0.1436 & 0.9960 & 0.1433 & 4 \\
$C_{4}$ & 0.1461 & 0.1455 & 0.1368 & 0.1457 & 0.1452 & 0.1455 & 0.1461 & 1.0109 & 0.1455 & 3 \\
$C_{5}$ & 0.1102 & 0.1167 & 0.1080 & 0.1145 & 0.1196 & 0.1167 & 0.1105 & 0.7962 & 0.1146 & 7 \\
$C_{6}$ & 0.1323 & 0.1344 & 0.1257 & 0.1337 & 0.1353 & 0.1344 & 0.1324 & 0.9283 & 0.1336 & 6 \\
$C_{7}$ & 0.1668 & 0.1620 & 0.1534 & 0.1636 & 0.1599 & 0.1620 & 0.1666 & 1.1342 & 0.1632 & 2 \\
Total & 1.0000 & 1.0000 & 1.0000 & 1.0000 & 1.0000 & 1.0000 & 1.0000 & 6.9493 & 1.0000 & \\
\hline
\end{tabular}

The ranking of the influential criteria weights was as follows: $C_{1}$ headquarters system $(0.1658)>C_{7}$ crisis management $(0.1632)>C_{4}$ location advantage $(0.1455)>C_{3}$ corporate imagination $(0.1433)>C_{2}$ human resources $(0.1340)>C_{6}$ marketing strategy $(0.1336)>C_{5}$ innovation and transformation (0.1146).

The results indicate that the three most important influential criteria were a headquarters system (0.1658), crisis management (0.1632), and location advantage (0.1455). Moreover, the four least 
important criteria were corporate imagination (0.1433), human resources (0.1340), marketing strategy (0.1336), and innovation and transformation (0.1146).

\subsection{The Influential Criteria Calculated to Acquire Weights for Possibilities of Outcomes}

Each influential criterion is represented in the franchise hospitality sector to allow KM implementation to enhance the probability of success [74]. For instance, in terms of the headquarters system criterion, if there have been smooth, strong operations, there will be an increased probability of successful KM implementation. Therefore, the organization's contribution, achievement, and performance are thought to have improved. By determining the priority weight matrix of possible outcomes compliant with each influential criterion, the linguistic terms for evaluators were determined (Table 3). Then, the prediction values of the two possible outcomes were calculated as follows:

(1) To assess the real situation of franchising hospitality within the pandemic period, the 15 evaluators were interviewed to evaluate which influential criterion can most easily be implemented to become successful. Table 12 lists the selections made by the 15 evaluators in terms of the preference intensity for the probability of success or failure compliant with each influential criterion.

Table 12. Linguistic variables describing the priority weight of two possible outcomes.

\begin{tabular}{|c|c|c|c|c|c|c|c|c|c|c|c|c|c|c|c|c|c|}
\hline & & $\mathbf{E}_{1}$ & $\mathrm{E}_{2}$ & $\mathrm{E}_{3}$ & $\mathrm{E}_{4}$ & $\mathrm{E}_{5}$ & $\mathrm{E}_{6}$ & $\mathrm{E}_{7}$ & $\mathrm{E}_{8}$ & $\mathrm{E}_{9}$ & $\mathbf{E}_{10}$ & $\mathbf{E}_{11}$ & $\mathrm{E}_{12}$ & $\mathrm{E}_{13}$ & $\mathbf{E}_{14}$ & $\mathrm{E}_{15}$ & \\
\hline & & F & F & $\mathbf{F}$ & F & F & F & F & F & F & F & F & F & F & F & $\mathbf{F}$ & \\
\hline$C_{1}$ & $S$ & $\mathrm{HF}$ & $\mathrm{H}$ & VHG & VHG & $\mathrm{H}$ & VHG & $\mathrm{H}$ & VHG & VHG & $\mathrm{H}$ & VHG & $\mathrm{VH}$ & VHG & VHG & $\mathrm{F}$ & $\overline{C_{1}}$ \\
\hline$C_{2}$ & $S$ & $\mathrm{~F}$ & $\mathrm{H}$ & VHG & $\mathrm{H}$ & $\mathrm{H}$ & VHG & LHF & LVHG & $\mathrm{H}$ & $\mathrm{F}$ & $\mathrm{H}$ & VHG & VH & VHG & $\mathrm{F}$ & $C_{2}$ \\
\hline$C_{3}$ & $S$ & VHG & $\mathrm{HF}$ & $\mathrm{F}$ & F & VHG & $\mathrm{HF}$ & LHF & VH & VHG & VHG & HF & VH & VHG & $\mathrm{VH}$ & $\mathrm{H}$ & $C_{3}$ \\
\hline$C_{4}$ & $S$ & $\mathrm{HF}$ & $\mathrm{H}$ & VHG & VHG & $\mathrm{VH}$ & VHG & VHG & $\mathrm{VH}$ & VHG & $\mathrm{F}$ & $\mathrm{VH}$ & $\mathrm{H}$ & $\mathrm{H}$ & LHF & $\mathrm{F}$ & $C_{4}$ \\
\hline$C_{5}$ & $S$ & $\mathrm{H}$ & VHG & $\mathrm{F}$ & $\mathrm{F}$ & LHF & $\mathrm{F}$ & LHF & LHF & VHG & $\mathrm{HF}$ & HF & VHG & $\mathrm{H}$ & $\mathrm{LH}$ & $\mathrm{H}$ & $C_{5}$ \\
\hline$C_{6}$ & $S$ & $\mathrm{HF}$ & VHG & VHG & $\mathrm{HF}$ & $\mathrm{HF}$ & $\mathrm{HF}$ & $\mathrm{F}$ & LH & $\mathrm{HF}$ & $\mathrm{H}$ & $\mathrm{H}$ & VH & VHG & VH & $\mathrm{F}$ & $C_{6}$ \\
\hline$C_{7}$ & $S$ & $\mathrm{H}$ & $\mathrm{H}$ & $\mathrm{H}$ & $\mathrm{H}$ & VHG & VHG & F & VHG & VHG & $\mathrm{H}$ & $\mathrm{H}$ & VHG & $\mathrm{VH}$ & VHG & $\mathrm{F}$ & $C_{7}$ \\
\hline
\end{tabular}

Note: $\mathrm{S}$ and $\mathrm{F}$ respectively indicate success and failure.

(2) The translation of linguistic variables into parallel numbers is illustrated in Table 3 Then, the function $i q_{u v}^{k}=\frac{1}{2}\left(1+\log _{5} i b_{u v}^{k}\right)$ was applied to transform the values within the scale $\left[\frac{1}{5}, 5\right]$ into the interval $[0,1]$. The preference data were transformed into the possible outcome of success, as shown in Table 13.

(3) The reciprocal additive transitivity property was then proposed, leading to the opposite comparison for failure shown in Table 14.

(4) The rating of possible outcomes could be synthetically acquired by applying Equation (21), as shown in Table 15. Equations (22) and (23) were then applied to synthesize and normalize the fuzzy preference rating of possible outcomes with respect to the seven influential criteria. The normalized values and priority weights are listed in Table 14. The calculations using ${ }_{1} \lambda_{S S, 1} \lambda_{S F, 1} \lambda_{F S}$ and ${ }_{1} \lambda_{F F}$ as examples are shown below.

$$
\begin{aligned}
& { }_{1} \lambda_{S S}=\frac{{ }_{1} q_{S S}}{{ }_{1} q_{S S}+{ }_{1} q_{F S}}=\frac{0.5}{0.5+0.1316}=0.7916 \\
& { }_{1} \lambda_{S F}=\frac{{ }_{1} q_{S F}}{{ }_{1} q_{S F}+{ }_{1} q_{F F}}=\frac{0.8684}{0.8684+0.5}=0.6346 \\
& { }_{1} \lambda_{F S}=\frac{{ }_{1} q_{F S}}{{ }_{1} q_{F S}+{ }_{1} q_{S S}}=\frac{0.1316}{0.1316+0.5}=0.2084 \\
& { }_{1} \lambda_{F F}=\frac{{ }_{1} q_{F F}}{{ }_{1} q_{F F}+{ }_{1} q_{S F}}=\frac{0.5}{0.5+0.8684}=0.3654
\end{aligned}
$$


Table 13. Transformed preference weight for possible outcome of "success".

\begin{tabular}{|c|c|c|c|c|c|c|c|c|c|c|c|c|c|c|c|c|c|c|}
\hline & & $\mathrm{E}_{1}$ & $\mathrm{E}_{2}$ & $E_{3}$ & $\mathrm{E}_{4}$ & $E_{5}$ & $\mathrm{E}_{6}$ & $\mathrm{E}_{7}$ & $\mathrm{E}_{8}$ & $\mathrm{E}_{9}$ & $\mathbf{E}_{10}$ & $\mathrm{E}_{11}$ & $\mathrm{E}_{12}$ & $\mathbf{E}_{13}$ & $\mathbf{E}_{14}$ & $\mathbf{E}_{15}$ & \multirow{2}{*}{ Total } & $q_{S F}$ \\
\hline & & F & F & $F$ & F & F & F & $F$ & F & F & F & F & F & F & F & F & & Average \\
\hline$C_{1}$ & $S$ & 0.7153 & 0.8413 & 0.9307 & 0.9307 & 0.8413 & 0.9307 & 0.8413 & 0.9307 & 0.9307 & 0.8413 & 0.9307 & 1.0000 & 0.9307 & 0.9307 & 0.5000 & 13.0260 & 0.8684 \\
\hline$C_{2}$ & S & 0.5000 & 0.8413 & 0.9307 & 0.8413 & 0.8413 & 0.9307 & 0.2847 & 0.0693 & 0.8413 & 0.5000 & 0.8413 & 0.9307 & 1.0000 & 0.9307 & 0.5000 & 10.7832 & 0.7189 \\
\hline$C_{3}$ & $\mathrm{~S}$ & 0.9307 & 0.7153 & 0.5000 & 0.5000 & 0.9307 & 0.7153 & 0.2847 & 1.0000 & 0.9307 & 0.9307 & 0.7153 & 1.0000 & 0.9307 & 1.0000 & 0.8413 & 11.9254 & 0.7950 \\
\hline$C_{4}$ & $S$ & 0.7153 & 0.8413 & 0.9307 & 0.9307 & 1.0000 & 0.9307 & 0.9307 & 1.0000 & 0.9307 & 0.5000 & 1.0000 & 0.8413 & 0.8413 & 0.2847 & 0.5000 & 12.1773 & 0.8118 \\
\hline$C_{5}$ & S & 0.8413 & 0.9307 & 0.5000 & 0.5000 & 0.2847 & 0.5000 & 0.2847 & 0.2847 & 0.9307 & 0.7153 & 0.7153 & 0.9307 & 0.8413 & 0.1587 & 0.8413 & 9.2593 & 0.6173 \\
\hline$C_{6}$ & $\mathrm{~S}$ & 0.7153 & 0.9307 & 0.9307 & 0.7153 & 0.7153 & 0.7153 & 0.5000 & 0.1587 & 0.7153 & 0.8413 & 0.8413 & 1.0000 & 0.9307 & 1.0000 & 0.5000 & 11.2100 & 0.7473 \\
\hline$C_{7}$ & $S$ & 0.8413 & 0.8413 & 0.8413 & 0.8413 & 0.9307 & 0.9307 & 0.5000 & 0.9307 & 0.9307 & 0.8413 & 0.8413 & 0.9307 & 1.0000 & 0.9307 & 0.5000 & 12.6319 & 0.8421 \\
\hline
\end{tabular}

Table 14. Opposite comparison matrix for possible outcome of "failure".

\begin{tabular}{|c|c|c|c|c|c|c|c|c|c|c|c|c|c|c|c|c|c|c|}
\hline & & $\mathbf{E}_{1}$ & $\mathrm{E}_{2}$ & $E_{3}$ & $E_{4}$ & $\mathbf{E}_{5}$ & $\mathrm{E}_{6}$ & $\mathrm{E}_{7}$ & $\mathrm{E}_{8}$ & $\mathrm{E}_{9}$ & $\mathbf{E}_{10}$ & $\mathrm{E}_{11}$ & $\mathbf{E}_{12}$ & $\mathbf{E}_{13}$ & $\mathrm{E}_{14}$ & $\mathbf{E}_{15}$ & \multirow{2}{*}{ Total } & $q_{F S}$ \\
\hline & & $S$ & $\mathrm{~S}$ & $\mathrm{~S}$ & $\mathrm{~S}$ & $\mathrm{~S}$ & $\mathrm{~S}$ & $\mathrm{~S}$ & $\mathrm{~S}$ & $\mathrm{~S}$ & $\mathrm{~S}$ & $\mathrm{~S}$ & $\mathrm{~S}$ & $\mathrm{~S}$ & $\mathrm{~S}$ & $S$ & & Average \\
\hline$C_{1}$ & F & 0.2847 & 0.1587 & 0.0693 & 0.0693 & 0.1587 & 0.0693 & 0.1587 & 0.0693 & 0.0693 & 0.1587 & 0.0693 & 0.0000 & 0.0693 & 0.0693 & 0.5000 & 1.9740 & 0.1316 \\
\hline$C_{2}$ & $\mathrm{~F}$ & 0.5000 & 0.1587 & 0.0693 & 0.1587 & 0.1587 & 0.0693 & 0.7153 & 0.9307 & 0.1587 & 0.5000 & 0.1587 & 0.0693 & 0.0000 & 0.0693 & 0.5000 & 4.2168 & 0.2811 \\
\hline$C_{3}$ & $\mathbf{F}$ & 0.0693 & 0.2847 & 0.5000 & 0.5000 & 0.0693 & 0.2847 & 0.7153 & 0.0000 & 0.0693 & 0.0693 & 0.2847 & 0.0000 & 0.0693 & 0.0000 & 0.1587 & 3.0746 & 0.2050 \\
\hline$C_{4}$ & F & 0.2847 & 0.1587 & 0.0693 & 0.0693 & 0.0000 & 0.0693 & 0.0693 & 0.0000 & 0.0693 & 0.5000 & 0.0000 & 0.1587 & 0.1587 & 0.7153 & 0.5000 & 2.8227 & 0.1882 \\
\hline$C_{5}$ & $\mathbf{F}$ & 0.1587 & 0.0693 & 0.5000 & 0.5000 & 0.7153 & 0.5000 & 0.7153 & 0.7153 & 0.0693 & 0.2847 & 0.2847 & 0.0693 & 0.1587 & 0.8413 & 0.1587 & 5.7407 & 0.3827 \\
\hline$C_{6}$ & F & 0.2847 & 0.0693 & 0.0693 & 0.2847 & 0.2847 & 0.2847 & 0.5000 & 0.8413 & 0.2847 & 0.1587 & 0.1587 & 0.0000 & 0.0693 & 0.0000 & 0.5000 & 3.7900 & 0.2527 \\
\hline$C_{7}$ & F & 0.1587 & 0.1587 & 0.1587 & 0.1587 & 0.0693 & 0.0693 & 0.5000 & 0.0693 & 0.0693 & 0.1587 & 0.1587 & 0.0693 & 0.0000 & 0.0693 & 0.5000 & 2.3681 & 0.1579 \\
\hline
\end{tabular}


Table 15. Normalized values and priority weights of possible outcomes with respect to seven criteria.

\begin{tabular}{llcccc}
\hline & & Success & Failure & Total & Average \\
\hline$C_{1}$ & Success & 0.7916 & 0.6346 & 1.4262 & 0.7131 \\
& Failure & 0.2084 & 0.3654 & 0.5738 & 0.2869 \\
$C_{2}$ & Success & 0.6401 & 0.5898 & 1.2299 & 0.6149 \\
& Failure & 0.3599 & 0.4102 & 0.7701 & 0.3851 \\
$C_{3}$ & Success & 0.7092 & 0.6139 & 1.3232 & 0.6616 \\
& Failure & 0.2908 & 0.3861 & 0.6768 & 0.3384 \\
$C_{4}$ & Success & 0.7266 & 0.6188 & 1.3454 & 0.6727 \\
& Failure & 0.2734 & 0.3812 & 0.6546 & 0.3273 \\
$C_{5}$ & Success & 0.5664 & 0.5525 & 1.1189 & 0.5595 \\
& Failure & 0.4336 & 0.4475 & 0.8811 & 0.4405 \\
$C_{6}$ & Success & 0.6643 & 0.5991 & 1.2635 & 0.6317 \\
& Failure & 0.3357 & 0.4009 & 0.7365 & 0.3683 \\
$C_{7}$ & Success & 0.7600 & 0.6275 & 1.3875 & 0.6937 \\
& Failure & 0.2400 & 0.3725 & 0.6125 & 0.3063 \\
\hline
\end{tabular}

\subsection{Determining the Prediction Values of Priority Weight}

Utilizing Equation (24), by multiplying the priority weight with the two possible outcomes, the prediction weights of the probabilities for success and failure of KM implementation could be determined, as shown in Table 16. For instance, the prediction weight was calculated as follows:

$$
\begin{aligned}
Z_{\text {success }}= & (0.7131 \times 0.1658)+(0.6149 \times 0.1340)+(0.6616 \times 0.1433)+(0.6727 \times 0.1455) \\
& +(0.5595 \times 0.1146)+(0.6317 \times 0.1336)+(0.6937 \times 0.1632)=0.6551, \\
Z_{\text {failure }=\quad} & (0.2869 \times 0.1658)+(0.3851 \times 0.1340)+(0.3384 \times 0.1433)+(0.3273 \times 0.1455) \\
& +(0.4405 \times 0.1146)+(0.3683 \times 0.1336)+(0.3063 \times 0.1632)=0.3449
\end{aligned}
$$

Table 16. Prediction of "success" and "failure" probabilities.

\begin{tabular}{ccccccccc}
\hline & $C_{1}$ & $C_{2}$ & $C_{3}$ & $C_{4}$ & $C_{5}$ & $C_{6}$ & $C_{7}$ & Prediction Probability \\
\hline Rank & 1 & 5 & 4 & 3 & 7 & 6 & 2 & \\
Priority Weight & 0.1658 & 0.1340 & 0.1433 & 0.1455 & 0.1146 & 0.1336 & 0.1632 & 1.0000 \\
Success & 0.7131 & 0.6149 & 0.6616 & 0.6727 & 0.5595 & 0.6317 & 0.6937 & 0.6551 \\
Failure & 0.2869 & 0.3851 & 0.3384 & 0.3273 & 0.4405 & 0.3683 & 0.3063 & 0.3449 \\
\hline
\end{tabular}

\section{Discussion}

\subsection{Factors}

The results illustrate that the three most important influential criteria were headquarters system (0.1658), crisis management (0.1632), and location advantage (0.1455). Moreover, the four least important criteria were corporate imagination (0.1433) human resources $(0.1340)$ marketing strategy (0.1336), and innovation and transformation (0.1146).

The predictive evaluation which collected franchising experts' opinions is illustrated in Figure 3, providing insight into the prediction results. This study indicated the values for success in seven influential criteria, summarized as $C_{1}$ headquarters system $(0.7131), C_{2}$ human resources (0.6149), $C_{3}$ corporate imagination (0.6616), $C_{4}$ location advantage $(0.6727), C_{5}$ innovation and transformation (0.5595), $C_{6}$ marketing strategy (0.6317), and $C_{7}$ crisis management (0.6937). These analytical results indicate that $C_{1}$ headquarters system (0.7131) and $C_{7}$ crisis management $(0.6937)$ were superior to other criteria. 


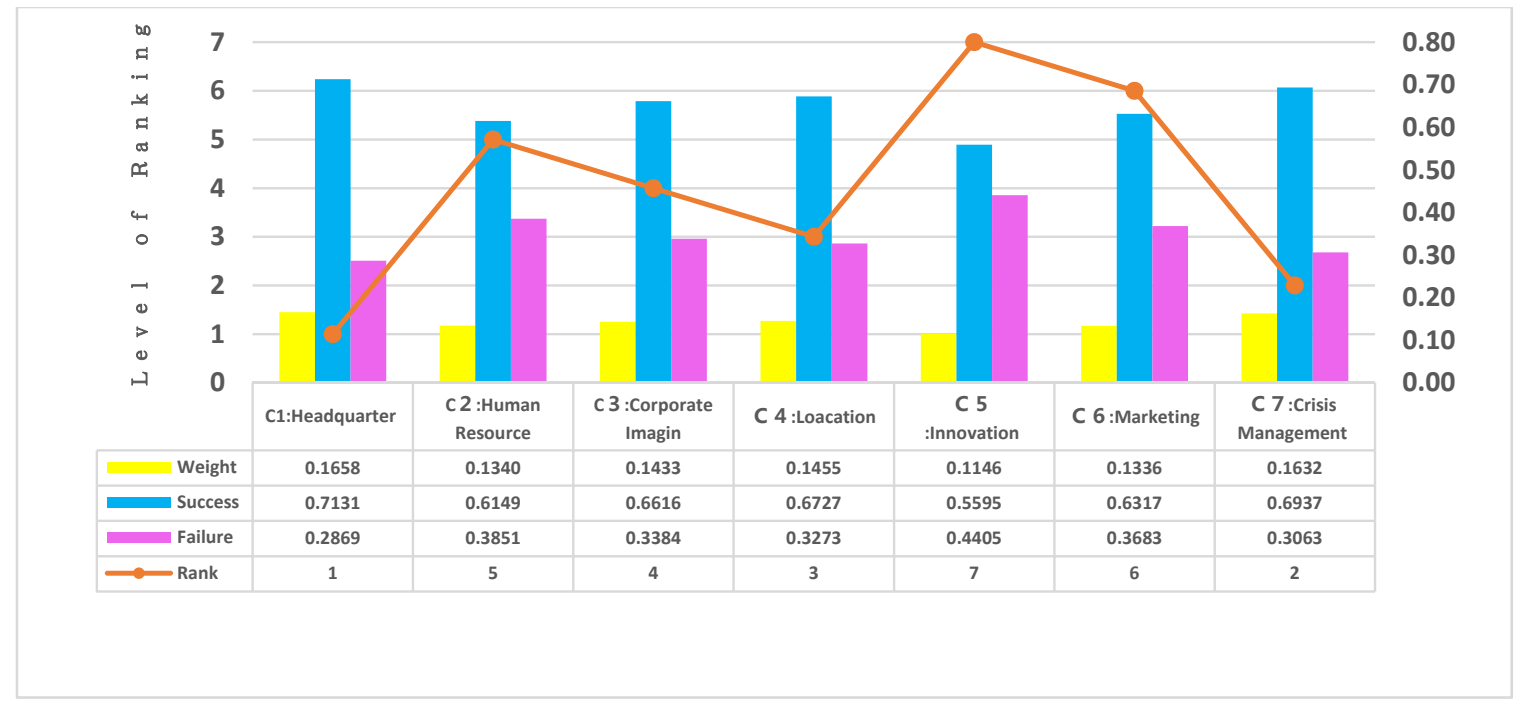

Figure 3. Influential ranking of criteria and prediction of success and failure.

On the other hand, the prediction values for failure among the seven influential criteria were as follows: $C_{1}$ headquarters system $(0.2869), C_{2}$ human resources $(0.3851), C_{3}$ corporate imagination $(0.3384), C_{4}$ location advantage (0.3273), $C_{5}$ innovation and transformation (0.4405), $C_{6}$ marketing strategy (0.3683), and $C_{7}$ crisis management (0.3063). Notably, failure had high probability for $C_{5}$ innovation and transformation (0.4405), $C_{2}$ human resource $(0.3851)$, and $C_{6}$ marketing strategy $(0.3683)$. This result also demonstrates that the franchising hospitality sectors should pay increased attention to enhancing innovation and transformation, human resources, and marketing strategy, especially due to the incidence of the COVID-19 outbreak being the single most significant change related to consumer behavior, organizational structure, and supply-chain management [39,75]. Therefore, franchising KM dynamic strategies and inspecting the resulting organizational model may achieve improvement through the KM implementation process, so that organizations can learn directly from the crisis. Predictive values disclosed that the probability of successful KM implementation (0.6551) to occur was approximately twice as high as the probability of failure (0.3449). This study described a compromised implication for franchise hospitality sectors to simultaneously implement knowledge management and some adjusted improvement actions to enhance the possibility of successful KM implementation and performance perspectives taken from this uncertain environment [76,77].

\subsection{Method}

Utilizing the CFPR model provides more advantages than the traditional AHP research method. Firstly, the CFPR method can not only decrease the number of survey items for the questionnaire, but also effectively reduce pairwise comparison frequency. For instance, when applying the traditional AHP research method require to design and answer $C_{2}^{7}=\frac{7 \times 6}{1 \times 2}=21$ questions, inconsistency frequently appears, whereas using CFPR only requires a design to answer $n-1=6$ questions. Secondly, computational simplicity is achieved by use of the CFPR method in order to relatively weigh each influential criterion. Thirdly, during the COVID-19 outbreak, industries and organizations should make accurate decisions quickly and objectively while applying CFPR for decision-making matrices that may enhance a guarantee of consistency in the decision-making process [13,72]. This study also pointed out the CFPR decision-making method can provide the best alternative to determining solutions during global crises.

\section{Conclusions}

This study stated some of the managerial difficulties and significant operational challenges encountered by the franchise hospitality sectors during a global crisis. The major challenge presented 
by the COVID-9 outbreak appears to be the dynamic and uncontrollable scenarios able to be decrypted by experts who have knowledge of how to manage this particular crisis situation [11,78,79]. However, even if organizations choose to collect such knowledge, the question remains whether they will have the initiative to utilize an appropriate prediction framework to examine potential implementation. For franchise hospitality sectors and partners, increasing profits, growing revenues, improving customer service, enhancing corporate reputation, and competitive competency are theoretical implications for KM implementation [80-82]. Appropriate KM implementation can lead to an organization's survival, whereas a predicted value of successful implementation can provide relevant information for decision-makers to quickly decide whether to implement $\mathrm{KM}$ or not. Knowledge management is a process that focuses on the headquarters system, human resources, corporate imagination, location advantage, marketing strategy, innovation and transformation, and crisis management issues.

A successful hospitality industry depends upon strategic KM. This is especially true when dealing with a franchise system. Franchise operations should provide the flexible managerial know-how and then transfer the various knowledge modes to assist partners in approaching market productivity and competition $[70,83]$. The key role of a headquarters is to recognize the nature of an organization, which will accelerate successful sustainability in recovery phases $[84,85]$. In addition, crisis management should strengthen the relationship between organization and industry in order to improve the chances of relevance and accuracy. The commitment to developing location as a market advantage can best enhance market-based productivity and competition [20,86,87].

The results of this study can be considered as a practical KM implementation case. Evaluating influential criteria from the franchise hospitality sectors to perceive instability in prediction processes furnishes decision-makers with dynamic criteria to make decisions regarding a crisis, e.g., whether it is best to implement KM, interdict adoption, or apply moderated improvements to enhance successful KM implementation $[88,89]$. The empirical results not only highlighted the three most significant influential criteria of headquarters system, crisis management, and location advantage in the KM-implemented process, but also disclosed KM's feasibility and applicability for solving complicated problems [90]. Consequently, entire industries and/or organizations can utilize the proposed prediction model to improve decision capacity and ability. This may provide a crisis management process to undertake appropriate actions, thus avoiding dangers or difficulties before preliminary KM [91,92].

\section{Limitations and Future Research Suggestions}

Despite this study's potential contributions, several limitations are indicated for future research. First, this study was conducted in an ongoing pandemic with the hospitality industry being the hardest hit. This study gives an overview of local franchise hospitality in Taiwan. As such, future research can be conducted to compare other types of industries, countries, and brands and sizes of franchise industries. Second, due to the prevention measures of social distancing, this study administered 15 expert surveys. In the future, research can enlarge the sample to increase the survey's level of validity and reliability. Third, the COVID-19 outbreak has receded in some areas; however, some questions and uncertainty surrounding KM implementation continuously exist regarding the best implementation method due to the relative novelty of KM. Finally, the lack of successful KM practices significantly obstructs business performance and competitive advantage in franchise hospitality. KM researchers recognize this phenomenon as a critical success criterion in establishing and maintaining performance and competitive advantage, specifically in service sectors and franchise-based businesses. The findings of this study revealed specific effective KM strategies for competitive advantage in the franchise hospitality industry. The three major themes emerging from the data as effective KM strategies were a headquarters system, crisis management, and location advantage. The importance of $\mathrm{KM}$ as a mechanism is paramount for franchise stakeholders to create or sustain competitive advantage in future research. Researchers are encouraged to pursue research in this challenging field.

Author Contributions: Conceptualization, H.-C.H., J.-Y.L. and T.-C.W.; methodology, H.-C.H., J.-Y.L. and T.-C.W.; software, H.-C.H. and T.-C.W.; validation, H.-C.H., J.-Y.L. and T.-C.W.; formal analysis, H.-C.H.; investigation, 
H.-C.H.; resources, H.-C.H.; data curation, H.-C.H. and X.-H.N.; writing-original draft preparation, H.-C.H.; writing-review and editing, H.-C.H., J.-Y.L. and T.-C.W.; visualization, X.-H.N.; supervision, J.-Y.L. and T.-C.W.; project administration, J.-Y.L. and T.-C.W.; funding acquisition, non. All authors have read and agreed to the published version of the manuscript.

Funding: This research received no external funding.

Conflicts of Interest: The authors declare no conflict of interest.

\section{References}

1. International Franchise Association. Available online: https://community.franchise.org/about-ifa (accessed on 15 September 2020).

2. Bretas, V.P.G.; Alon, I. The impact of COVID-19 on franchising in emerging markets: An example from Brazil. Glob. Bus. Organ. Excell. 2020, 39, 6-16. [CrossRef]

3. Pellegrini, M.; Ciampi, F.; Orland, B. The relationship between knowledge management and leadership: Mapping the field and providing future research avenues. J. Knowl. Manag. 2020, 24, 1-48. [CrossRef]

4. Crick, J.; Crick, D. Coopetition and COVID-19: Collaborative business-to-business marketing strategies in a pandemic crisis. Ind. Mark. Manag. 2020, 88, 206-213. [CrossRef]

5. Tsionas, M. COVID-19 and gradual adjustment in the tourism, hospitality, and related industries. Tour. Econ. 2020. [CrossRef]

6. Wang, T.C.; Hsieh, H.C. An Analysis of Diversity Management for a Diverse Workforce in the Hospitality and Tourism Industry. Adv. Manag. Sci. 2016, 5, 32-36.

7. Hadi, S.; Supard, S. Revitalization Strategy for Small and Medium Enterprises after Corona Virus Disease Pandemic (COVID-19) in Yogyakarta. J. Xi'an Univ. Archit. Technol. 2020, 4, 4068-4076.

8. Fong, L.; Law, R.; Ye, B. Outlook of tourism recovery amid an epidemic: Importance of outbreak control by the government. Ann. Tour. Res. 2020, in press. [CrossRef]

9. Bargeman, B.; Richards, G. A new approach to understanding tourism practices. Ann. Tour. Res. 2020, 84, 102988. [CrossRef]

10. Karim, W.; Haque, A.; Anis, Z.; Ulfy, M. The Movement Control Order (MCO) for COVID-19 Crisis and its Impact on Tourism and Hospitality Sector in Malaysia. Int. Tour. Hosp. J. 2020, 3, 1-7.

11. Noble, J. Competition law in times of crisis-tackling the COVID-19 challenge: A producer perspective. J. Antitrust Enforc. 2020, 8, 293-295. [CrossRef]

12. Wang, T.C.; Chang, T.H. Application of consistent fuzzy preference relations in predicting the success of knowledge management implementation. Eur. J. Oper. Res. 2007, 182, 1313-1329. [CrossRef]

13. Li, D.; Guo, H.; Wang, X.; Liu, Z.; Li, C.; Wang, W. Analyzing the Effectiveness of Policy Instruments on New Energy Vehicle Industry using Consistent Fuzzy Preference Relations. Int. Rev. Spat. Plan. Sustain. Dev. 2016, 4, 45-57. [CrossRef]

14. Aliperti, G.; Cruz, A. Promoting built-for-disaster-purpose mobile applications: An interdisciplinary literature review to increase their penetration rate among tourists. J. Hosp. Tour. Manag. 2020, 44, 193-210. [CrossRef]

15. Thorgren, S.; Williams, T. Staying alive during an unfolding crisis: How SMEs ward off impending disaster. J. Bus. Ventur. Insights 2020, 14, e00187. [CrossRef]

16. Tussyadiah, I. A review of research into automation in tourism: Launching the Ann. Tour. Res. Curated Collection on Artificial Intelligence and Robotics in Tourism. Ann. Tour. Res. 2020,81, 102883. [CrossRef]

17. Aldaco, R.; Heohn, D.; Laso, J.; Margallo, M.; Ruin-Salmon, J.; Cristobal, J. Food waste management during the COVID-19 outbreak: A holistic climate, economic and nutritional approach. Sci. Total Environ. 2020, 742, 140524. [CrossRef]

18. Dhir, A.; Talwar, S.; Kaur, P.; Malibari, A. Food waste in hospitality and food services: A systematic literature review and framework development approach. J. Clean. Prod. 2020, 270, 122861. [CrossRef]

19. Dolnicar, S.; Juvan, E.; Grün, B. Reducing the plate waste of families at hotel buffets-A quasi-experimental field study. Tour. Manag. 2020, 80, 104103. [CrossRef]

20. Giones, F.; Brem, A.; Pollack, J.; Michaelis, T.; Klyver, K.; Birnckmann, J. Revising entrepreneurial action in response to exogenous shocks: Considering the COVID-19 pandemic. J. Bus. Ventur. Insights 2020, 14, e00186. [CrossRef] 
21. Shaw, R.; Kim, Y.K.; Hua, J. Governance, technology and citizen behavior in pandemic: Lessons fromCOVID-19 in Ease Asia. Prog. Disaster Sci. 2020, 6, 100090. [CrossRef]

22. Kim, J.; Lee, J. Effect of COVID-19 on Preference for Private Dining Facilities in Restaurants. J. Hosp. Tour. Manag. 2020, 45, 67-70. [CrossRef]

23. Chou, S.F.; Horng, J.S.; Liu, C.H.; Huang, Y.C.; Zhang, S.N. The Critical criteria for innovation entrepreneurship of restaurants: Considering the interrelationship effect of human capital and competitive strategy a case study in Taiwan. J. Hosp. Tour. Manag. 2020, 42, 222-234. [CrossRef]

24. Karabulut, G.; Bilginb, M.H.; Demir, E.; Doker, A.C. How pandemics affect tourism: International evidence. Ann. Tour. Res. 2020, 84, 3579530. [CrossRef]

25. Kloutsiniotis, P.; Mihail, D. The effects of high performance work systems in employees' service-oriented OCB. Int. J. Hosp. Manag. 2020, 90, 102610. [CrossRef] [PubMed]

26. Berhanu, K.; Raj, S. The trustworthiness of travel and tourism information sources of social media: Perspectives of international tourists visiting Ethiopia. Heliyon 2020, 6, e03439. [CrossRef] [PubMed]

27. Brookes, M.; Altinay, L. Knowledge Transfer and isomorphism in Franchise Network s. Int. J. Hosp. Manag. 2017, 62, 33-42. [CrossRef]

28. Cumberland, D.; Githens, R. Tacit Knowledge Barriers within Franchise Organizations. In Proceedings of the AHRD 2010 Americas Conference, Louisville, KY, USA, 24-28 February 2020; pp. 1278-1302.

29. Khan, N.; Khan, A.; Soomro, M.; Khan, S. Transformational leadership and civic virtue behavior: Valuing act of thriving and emotional exhaustion in the hotel industry. Asia Pac. Manag. Rev. 2020, in press. [CrossRef]

30. Achary, V.; Borchert, L.; Jager, M.; Steffen, S. Kicking the can down the road: Government interventions in the European banking sector. In Proceedings of the Financial Crisis Ten Years Afterwards Conference, Mannheim, Germany, 2-3 August 2018; pp. 1-62.

31. Aladag, O.; Köseoglu, M.; Kingb, B.; Mehraliyev, F. Strategy implementation research in hospitality and tourism: Current status and future potential. Int. J. Hosp. Manag. 2020, 88, 102556. [CrossRef]

32. Sigala, M. Tourism and COVID-19: Impacts and implications for advancing and resetting industry and research. J. Bus. Res. 2020, 117, 312-321. [CrossRef]

33. Cetin, G.; Demirciftci, T.; Bilgihan, A. Meeting Revenue Management Challenges: Knowledge, Skills and abilities. Int. J. Hosp. Manag. 2016, 57, 132-142. [CrossRef]

34. Willis Towers Wastson. Global Crisis: Human Capital Road Map; Willis Towers Wastson: London, UK, 2020.

35. Wohlfarth, K.; Worrell, E.; Eichhammer, W. Energy efficiency and demand response-two sides of the same coin? Energy Policy 2020, 137, 111070. [CrossRef]

36. Wu, C.W. Antecedents of franchise strategy and performance. J. Bus. Res. 2020, 68, 1581-1588. [CrossRef]

37. Köseoglua, M.; Altinb, M.; Chan, E.; Aladag, O. What are the key success factors for strategy formulation and implementation? Perspectives of managers in the hotel industry. Int. J. Hosp. Manag. 2020, 89, 102574. [CrossRef] [PubMed]

38. Nicola, M.; Alsafi, Z.; Sohrabi, C.; Kerwan, A.; Al-Jabir, A. The socio-economic implications of the coronavirus pandemic (COVID-19): A review. Int. J. Surg. 2020, 78, 185-193. [CrossRef] [PubMed]

39. Zhang, C.; Wang, S.; Sun, S.; Wei, Y. Knowledge mapping of tourism demand forecasting research. Tour. Manag. Perspect. 2020, 35, 100715. [CrossRef] [PubMed]

40. Zheng, Y.; Goh, E.; Wen, J. The effects of misleading media reports about COVID-19 on Chinese tourists' mental health: A perspective article. Anatolia 2020, 31, 337-340. [CrossRef]

41. Chen, Y.Y.; Huang, H.L. The Knowledge Management Strategic Alignment Model (KMSAM) and Its Impact on Performance: An Empirical Examination. In Knowledge Management; IntechOpen: London, UK, 2010; pp. 25-34.

42. Melao, N.; Reisb, J. Selecting talent using social networks: A mixed-methods study. Heliyon 2020, 6, e03723. [CrossRef]

43. Xu, D.; Pearce, P.; Chen, T. Deconstructing tourist scams: A social-practice-theory perspective. Tour. Manag. 2020, 82, 104186. [CrossRef]

44. Martin-Rios, C.; Ciobanu, T. Hospitality innovation strategies: An analysis of success factors and challenges. Tour. Manag. 2019, 70, 218-229. [CrossRef]

45. Grewal, D.; Iyer, G.; Javalgi, R.; Radulovic, L. Franchise partnership and international expansion: A conceptual framework and research propositions. Entrep. Theory Pract. 2011, 35, 535-557. [CrossRef]

46. Hao, F.; Xiao, Q.; Chon, K. COVID-19 and China's Hotel Industry: Impacts, a Disaster Management Framework, and Post-Pandemic Agenda. Int. J. Hosp. Manag. 2020, 90, 102636. [CrossRef] 
47. Altinay, L. The internationalization of hospitality firms: Factors influencing a franchise decision-making process. J. Serv. Mark. 2007, 21, 398-409. [CrossRef]

48. Altinay, L.; Brookes, M. Factors influencing relationship development in franchise partnerships. J. Serv. Mark. 2012, 4, 278-292. [CrossRef]

49. Bartik, A.; Bertrand, M.; Cullen, Z.; Glaeser, E.; Luca, M.; Stanton, C. How Are Small Business Adjusting to COVID-19? Early Evidence from a Survey; National Bureau of Economic Research: Cambridge, MA, USA, 2020.

50. Wang, T.C.; Hsieh, H.C. Crisis Management in Tourism Industry. Int. J. Bus. Manag. Res. 2016, 6, 97-102.

51. Herrera-Viedma, E.; Herrera, F.; Chiclana, F.; Luque, M. Some issues on consistency of fuzzy preference relations. Eur. J. Oper. Res. 2004, 154, 98-109. [CrossRef]

52. Herrera-Viedma, E.; Alonso, S.; Chiclana, F.; Herrera, F. A Consensus Model for Group Decision Making with Incomplete Fuzzy Preference Relations. IEEE Trans. Fuzzy Syst. 2007, 15, 863-877. [CrossRef]

53. Wang, T.C.; Hsieh, H.C.; Hsu, S.C. Predicting the Success of Promoting a Decision-maker's Judgment by InLinPreRa. In Proceedings of the International Conference on Business and Management, Shenzhen, China, 20 January 2016; pp. 1-6.

54. Khan, Z. Determinants of a Successful Cross-Border Knowledge Transfer in Franchise Networks. J. Asia Bus. Stud. 2016, 10, 148-163. [CrossRef]

55. Collier, R.; Pirlot, A.; Vella, J. Tax Policy and the COVID-19 Crisis; Oxford University Centre for Business Taxation: Oxford, UK, 2020.

56. Cortes-Sanchez, J. A bibliometric outlook of the most cited documents in business, management and accounting in Ibero-America. Eur. Res. Manag. Bus. Econ. 2020, 26, 1-8. [CrossRef]

57. Navajas-Romero, V.; Díaz-Carrión, R.; Casas-Rosalc, J. Comparing working conditions and job satisfaction in hospitality workers across Europe. Int. J. Hosp. Manag. 2020, 90, 102631.

58. Rainone, K.; Grootendorst, G. Economic Impacts of COVID-19: Estimates for Hampton Roads; Hampton Roads Planning District Commission: Chesapeake, VA, USA, 2020.

59. Rephann, T. COVID-19 Economic and Tax Revenue Impacts: Estimates for the Commonwealth of Virginia and Localities; Center for Economic and Policy Studies Weldon Cooper Center for Public Service University of Virginia: Virginia, VA, USA, 2020.

60. Ruparel, N.; Dhir, A.; Tandon, A.; Islam, J. The influence of online professional social media in human resource management: A systematic literature review. Technol. Soc. 2020, 63, 10133. [CrossRef]

61. Badrinarayanan, V.; Suh, T.; Kim, K.M. Brand resonance in franchising relationships A franchise-based presecptive. J. Bus. Res. 2016, 69, 3943-3950. [CrossRef]

62. Mazurek, M. The Innovation Approach to Rish Management as a Part of Destination Competitiveness and Reputation; Faculty of Humanities, University of Zilina: Zilina, Slovakia, 2020.

63. Kuhzady, S.; Çakici, C.; Olya, H.; Mohajer, B.; Han, H. Couch surfing involvement in non-profit peer-to-peer accommodations and its impact on destination image, familiarity, and behavioral intentions. J. Hosp. Tour. Manag. 2020, 44, 131-142. [CrossRef]

64. Sa, M.; Choon-Yin, S.; Kim, Y. Knowledge creation process, customer orientation and firm performance: Evidence from small hotels in Malaysia. Asia Pac. Manag. Rev. 2020, 25, 65-74.

65. Damnjanović, V.; Lončarić, D.; Dlačić, J. Digital marketing strategy of Accor Hotels: Shaping the future of hospitality. Tour. Hosp. Manag. 2020, 26, 233-244.

66. Raudeliūnienè, J.; Davidavičienè, V.; Jakubavičis, A. Knowledge management process model. Entrep. Sustain. Issues 2018, 5, 542-554.

67. Kwok, L.; Tang, Y.; Yu, B. The 7 Ps marketing mix of home-sharing services: Mining travelers' online reviews on Airbnb. Int. J. Hosp. Manag. 2020, 90, 102616. [CrossRef]

68. Collins-Kreiner, N. A review of research in to religionand tourism Launching the Ann. Tour. Res. Curated Collection on religionand tourism. Ann. Tour. Res. 2020, 82, 1-22. [CrossRef]

69. Rittichainuwat, B.; Laws, E.; Maunchontham, R.; Rattanaphinanchai, S.; Muttamara, S.; Moutona, K. Resilience to crises of Thai MICE stakeholders: Alongitudinal study of the destination image of Thailand as a MICE destination. Tour. Manag. Perspect. 2020, 35, 100704. [CrossRef]

70. Isa, R.; Abdullah, N.; Hamzah, N.; Arshad, R. The Typology of Intellectual Capital and Knowledge Management in Malaysian Hotel Industry. J. Hum. Resour. Adult Learn. 2008, 4, 103-114.

71. Herrera-Viedma, E.; Francisco, C.; Herrera, F.; Alonso, S. Group Decision-Making Model with Incomplete Fuzzy Preference Relations Based on Additive Consistency. IEEE Trans. Syst. Man Cybern. 2007, 37, 176-189. [CrossRef] 
72. Chao, R.J.; Chen, Y.H. Evaluation of the criteria and effectiveness of distance e-learning with consistent fuzzy preference relations. J. Adv. Transp. 2009, 36, 10657-10662. [CrossRef]

73. Wang, T.C.; Wang, C.N.; Nguyen, X.H. Evaluating the Influence of Criteria to Attract Foreign Direct Investment (FDI) to Develop Supporting Industries in Vietnam by Utilizing Fuzzy Preference Relations. Sustainability 2016, 8, 447. [CrossRef]

74. Yeung, R.; Brookes, M.; Altinay, L. The hospitality franchise purchase decision-making process. Int. J. Contemp. Hosp. Manag. 2016, 28, 1009-1025. [CrossRef]

75. Verma, S.; Gustafsson, A. Investigating the emerging COVID-19 research trends in the field of business and management: A bibliometric analysis approach. J. Bus. Res. 2020, 118, 253-261. [CrossRef] [PubMed]

76. Teo, S.; Bentley, T.; Nguyen, D. Psychosocial work environment, work engagement, and employee commitment: Amoderated, mediation model. Int. J. Hosp. Manag. 2020, 88, 102415. [CrossRef]

77. Tiago, F.; Gil, A.; Stemberger, S.; Borges-Tiago, T. Digital sustainablility communication in tourism. J. Innov. Knowl. 2020, 12, 5324.

78. Laguna, L.; Fiszman, S.; Puerta, P.; Chaya, C.; Tárrega, A. The impact of COVID-19 lockdown on food priorities. Results from a preliminary study using social media and an online survey with Spanish consumers. Food Qual. Prefer. 2020, 86, 104028. [CrossRef]

79. Tajeddini, K.; Martin, E.; Ali, A. Enhancing hospitality business performance: The role of entrepreneurial orientation and networking ties in a dynamic environment. Int. J. Hosp. Manag. 2020, 90, 102605. [CrossRef]

80. Ayup-Gonzalez, J.; Calderon-Monge, E.; Carrilero-Castillo, A. The effects of management and environmental factors on franchise continuity. Econ. Res. Ekon. Istraž. 2019, 32, 4059-4074. [CrossRef]

81. Salinga, K.; Doa, M. Leveraging People Analytics for an Adaptive Complex Talent Management System. Procedia Comput. Sci. 2020, 168, 105-111. [CrossRef]

82. Sundqvist, J.; Walter, U.; Hörnell, A. Meal identity as practice-Towards an understanding of business travellers' meal practices. Int. J. Gastron. Food Sci. 2020, 22, 100237. [CrossRef] [PubMed]

83. Higgins-Desbiolles, F. Socialising tourism for social and ecological justice after COVID-19. Tour. Geogr. 2020, 22, 610-623. [CrossRef]

84. Zenker, S.; Kock, F. The coronavirus pandemic-A critical discussion of a tourism research agenda. Tour. Manag. 2020, 81, 104164. [CrossRef]

85. Zhang, K.; Hou, Y.; Li, G. Threat of infectious disease during an outbreak: Influence on tourists' emotional responses to disadvantaged price inequality. Ann. Tour. Res. 2020, 84, 102993. [CrossRef] [PubMed]

86. Choia, S.H.; Ling, Y.E.; Tabari, S. Solodining in Chinese restaurants: Amixed-method study in Macao. Int. J. Hosp. Manag. 2020, 90, 102628. [CrossRef] [PubMed]

87. Gössling, S.; Scott, D.; Hall, C. Pandemics, tourism and global change: A rapid assessment of COVID-19. J. Sustain. Tour. 2020, 48, 39-51.

88. Sándorová, Z.; Repáňová, T.; Palenčíková, Z.; Beták, N. Design thinking-Are volutionary new approach in tourism education? J. Hosp. Leis. Sport Tour. Educ. 2020, 26, 100238.

89. Sharma, P.; Leung, T.; Kingshott, R.; Davcik, N.; Cardinali, S. Managing uncertainty during a global pandemic: An international business perspective. J. Bus. Res. 2020, 116, 188-192. [CrossRef]

90. García-Milon, A.; Juaneda-Ayensa, E.; Olarte-Pascual, C.; Pelegrín-Borondo, J. Towards the smart tourism destination: Key factors in information source use on the tourist shopping journey. Tour. Manag. Perspect. 2020, 36, 100730. [CrossRef]

91. Guzmán, V.; Muschard, B.; Gerolamo, M.; Kohl, H.; Rozenfeld, H. Characteristics and Skills of Leadership in the Context of Industry. Sci. Direct Procedia Manuf. 2020, 43, 543-550. [CrossRef]

92. Purcell, L.; Charles, A. An Invited Commentary on "World Health Organization declares global emergency: A review of the 2019 novel Coronavirus (COVID-19)": Emergency or newreality? Int. J. Surg. 2020, 76. [CrossRef] [PubMed]

Publisher's Note: MDPI stays neutral with regard to jurisdictional claims in published maps and institutional affiliations. 